\title{
Clash of Civilisations: Tonga and the West
}

\section{Abstract}

The House thanks God that the king is still in good health, and the Monarch is still in control of the affairs of the country. We thank god for the assistance to Tonga from donor countries (Lord Lasike cited in Matangi Tonga, 2011).

At the first 2011 session of Tonga's legislative assembly on June 9th the House was busy thanking god for king and aid donors, a variation to king and country, the usual saying. Tongan journalist Pesi Fonua poked fun at the country's lawmakers by translating the parliamentary minutes into English for publication on his media website. The original Hansard transcript in the Tongan language might not have been altogether amusing, but rather, standard convention for formally addressing the monarch. However, one question that Fonua brought to light was at this time in Tonga's history when a more democratic government was said to have taken the helm, had the hierarchal structure really changed? Furthermore, why had "donor countries" crept into the state's salutations to the king, and which countries were Tongan 
politicians thinking of - Western ones or China? (Matangi Tonga, 2011).

Personifying a Western-centred view of Tonga's political system, New Zealand researcher of constitutional law Guy Powles made a brash commentary to Radio Australia. As a Palangi (white, European) observer, Powles presumptuously displayed his over-confidence in giving advice to Tonga. Claiming the Tongan "constitution does need to be studied in detail," he felt certain "there are areas there of what one might call unfinished business." Specifically, "the original principle hasn't been carried through, that is the devolution of executive authority" (Powles cited in Garrett, 2014).

Powles was pointing at executive powers the monarch held onto compared to the ones which were handed over to the prime minister and the national executive by constitutional amendment in 2010. Did reasonable expectation surface among the Tongan public that in the near future, all of the King's executive authority would be delegated to the state? Or could this be read as an explicit case of the Western ego fantasising that all Pacific Island states naturally desired to remake their civilizations and sovereignty in their likeness?

This essay pokes the polemics and pragmatics of Tongan civilization enacted in modern times through a distinct set of cultural values. How has the tenacity of Tongan civilization in today's globalized world run into trouble with Western development partners - New Zealand, Australia, and America especially when it comes to Tonga's foreign relations? (International Business Publications, 2011).

\section{There is something peculiar}

I ought to be grateful my mother sent me to Tonga as a child because it has stopped me from becoming completely integrated into Western society as a New Zealand citizen, as 
well as living with hopeless ignorance of how the oldest and only remaining South Pacific Kingdom manoeuvres in real politick. I cannot say the same for fellow Tongans born and raised in New Zealand, particularly those who research in academia and show little, if any inclination to publish about Tonga. Effectively this is a wise choice because if they did, I am certain they would surely get Tonga mixed up and confused with their Kiwi oriented value judgements about Pasifika peoples, the New Zealand government's made-up label forced on top of anyone and everyone living in New Zealand who claims Pacific Islander ethnicity.

I detest being name-called Pasfika in Auckland where I work and live. Then again, it might sound less offensive than being termed something ludicrous like Lapita pottery peoples, or having to wear the sweeping categorization of ethnic minority. Any individual or group fitted with ethnic minority grows an acute awareness that the label is designed to contain and control a diverse mass under the bureaucratic weight of naming things, especially alien things not considered the standard norm for an ex-British settler colony like New Zealand.

The race accepted as normal here continues to be white people of Western European descent, despite history showing us that the islands constituting this country were first settled by indigenous Maori tribes who are Polynesian by the Western European logic of race classification. References to Palangi or Pakeha in New Zealand, meaning white European, are choosy precluding individuals and groups of Eastern European decent.

Similar to other settler societies founded under the 19th century British Empire, the line of ethnic and cultural distinction had been drawn between Western and Eastern Europe. Eastern Europe crossed the border into Eurasia and central Asian civilizations, blurring the boundaries of pure and 
proper European identity. By contrast, Western Europe was counted as the real Europe; civilized, cultivated, liberal, wealthier, and the quintessential Pakeha New Zealander's origin roots. Whether in actual fact this was true did not matter. Represented was a cultural truth New Zealanders were enduringly socialised to believe preserving the usual myths and legends about national identity.

Whatever the case with New Zealand's racial hierarchy, there was something peculiar about the way in which adults born in New Zealand formed opinions about how the homeland state where their parents and grandparents were born should progress, advance, and develop into a kind of mini South Auckland. Their interpretive bias was very Palangi (white, European). Overwhelmingly their thinking replicated what New Zealanders understood as Pasifika peoples congregating inside their national borders. Why would the Kingdom of Tonga want to evolve into Otara and Mangere flea markets on a Saturday morning as the New Zealand icon of Pacific Islanders trading and bartering in the modern world economy?

Plainly this was not the role model of development Tongans in the homeland state envisaged for themselves. If the truth be told, in Tonga people expressed scepticism about the fact their New Zealand Tongan counterparts were disadvantaged by economic and social barriers to employment, education, and living standards on par with Palangi (white, European) New Zealanders. Forty years of mass migration had witnessed Tongans resettle in New Zealand and grow into sizeable communities by natural birth rates. Why had their lot in life not improved across generations to the point where they were now branded as New Zealand's urban poor?

What I am saying is that by homeland Tongan calculations, New Zealanders had a cheek to preach to their government about economic and social development (Aotearoa, 
2014). How far had New Zealand state and society developed since the 1960s and 1970s labour market influx of Pacific Islanders as unskilled and low-paid factory workers? Why was the New Zealand Pacific population crowned by its consecutive state administrations as most likely to not have paid employment and tertiary education, and least likely to vote in general and local elections? Given the grave disparity between Pakeha and Pasifika peoples in New Zealand, how could New Zealand claim any moral high ground of supposedly knowing what is progress for Pacific Island states to lecture Tonga on how to run their state affairs? (Bhattacharya, 1983).

Polish academic Zygmunt Bauman who at eighty-eight years old is the emeritus professor of sociology at the University of Leeds, explained "the major source of contemporary fear" which can be said had seized New Zealand state and society (Bauman, 2011). Put simply, the distress and dread that "no one is in control" of the contemporary world as people experienced it in their day-to-day lives fed the human condition of perpetual uncertainty and insecurity (Bauman, 2011).

No one is in control. That is the major source of contemporary fear. The fears are scattered. The fears are diffused. You can't pinpoint the sources where from they are coming. They seem to be ubiquitous. They seem to apply as much of a private life as a life in common, the social life; all sorts of things might happen. It could be a tsunami. It could be Hurricane Katrina. It could be another earthquake. It could be a sudden closing up of the factory in which you worked for twenty years. Or, a hostile merger between two offices and you are losing your job. It may be collapse of the stock exchange and you're losing your old age pension and the savings you've made for many, many years. It could be another 
terrorist attack. There could be sudden street riots and your shop is destroyed and burned; your car is stolen or burned, and so on. In other words, it seems we are living on quick sands. Every movement that you want to make to stabilise or position may have quite opposite consequences like quick sands; you may sink even deeper than before. (Bauman, 2011).

Bauman's "source of contemporary fear," which is the unpredictability of economic life in a neoliberal environment where the combined power of banks, corporations, and open market trade dominated the state, which in turn, compounded the fragility of human security, was also the global condition Tonga contended with. One striking difference between New Zealand and Tonga was historically the New Zealand state had been the colonial administration governing the Pacific Island states of Samoa, Tokelau, the Cook Islands, and Niue. New Zealand saw it had a great deal of trade and political weight to lose if it did not take charge of its sphere of influence in the South Pacific (Firth, 2006). Particularly, the Polynesian states of Tonga, Samoa, the Cook Islands, Niue, Tuvalu, and Tokelau comprised the foreign domain in which New Zealand exercised its paternalistic and patronising authority.

And here lies the crux of my essay's inquiry: What political behaviour has New Zealand in collaboration with its Western allies Australia and the United States of America exerted with coercive will to pull dissenting Pacific Island states into line? (Folau, 2014; Fonua, 2014) I am referring to the West's predisposition for containment and control over historical spheres of influence as in the Pacific region, which in a new world order were witnessing fast-changing foreign relations realised by the pivot to China and the East. Is Tonga a dissenting state? Or has the re-emergence of Tongan 
civilization and cultural difference to the West appeared for a context-specific set of reasons?

Presently, the Tongan state seeks to control the political messiness and abstruseness of reconciling constitutional monarchy and Western liberal democracy on its own terms of pragmatism and practicability. What are those terms, exactly? Moreover, why is history and culture the fundamental basis for Tonga's political trademark as the last remaining South Pacific Kingdom, the oldest civilization, and a young democracy at a time when "no one is in control" of a new world order?

\section{Stuck on democracy}

It was my half-cast mother, Ruby Veronica Kathleen Patricia Brown, who during my childhood put me on a flight to Tonga every summer vacation to visit her sister Tina Brown whom she named me after. I objected to going, mostly. Six weeks in Tonga for the festive season was sacrificial. I felt like a martyr giving up my indulged New Zealand life for home detention; locked up in the house with a controlling aunt who ordered me to play the piano and read books to pass the time of day.

I was, however, fond of my mother's three older sisters who remained in Tonga, Nina, Tina, and Deanne. Now, as a middle-age working mother I can appreciate that they stayed in this small island developing state when their siblings fled for overseas incomes and living standards with straightforward access to New Zealand as their country of permanent residence because of British citizenship and passports they inherited through paternity.

As a child Tonga's summer heat, mosquitoes, and my Aunty Tina's strictness were barely bearable. As a teenager the boredom was torturous, especially when my friends in New Zealand were holidaying at the beach and afforded the social 
freedom that middle-class teenagers of developed countries were accustomed to.

From the New Zealand lifestyle I knew, approaching eighteen years old and near ready to leave home for university bred a feeling of entitlement to experiment with social markers of adulthood, especially alcohol, parties, bars, and boys. The Tonga experience I was dropped into were Christmas and New Year holidays in my mother's family homestead under the sheltered and strict surveillance of her sister, invoking an enduring sense of familial convention, familiarity, and frustration.

I say enduring because I research and publish about Tonga as an academic career choice. Consciousness of familial convention, familiarity, and frustration revisits my memory. It is knotted into the political landscape and reiterated throughout my writing. In many ways this essay unravels the complexity of understanding how Tongan civilization is made sense of today and stage-managed by the state as the cultural basis of its foreign relations with Western aid donors. My analytical lens is focused on inconsistency.

What I mean is that Western research and media have overlooked the importance of how, and by what means, cultural values have been systematically practiced in democratising the Tongan state. Consequently, an intricate detail has gone amiss in their analyses. How has the clash of Tongan civilization and Western liberal democracy been sorted out according to Tongan conditions of workability, not Western prerequisites for becoming more like them and less like us?

There is little, if anything, in the present day that is ad hoc about how culture is imagined into existence as part-andparcel of Tonga's 1875 constitution instated under King George Tupou I as the nation's first statutory monarch. To the contrary, however, there have been random and muddled reactions against convention in which it is proposed and 
insinuated, but never publicised and proclaimed, that democracy is partially finished.

The notion that Tonga will gradually achieve democracy bit-by-bit had not resulted in singling out the monarch as the culprit blocking progress. Contradicting Western scepticism, the people's representatives in a post-2010 democratised parliament did not petition the King of Tonga to give up all of his executive authority; nor was it likely a request from below, from the commoner members of parliament that is, would be made to the reigning monarch after the 2014 general election demanding he relinquish his power (Bhattacharya, 1983).

Instead, the nobles were purposefully focused on as an object of discontent (Matangi Tonga, 2014a, 2014b). Criticising the new parliamentary and government system involved crafting a scapegoat to blame for its assumed inadequacy in not ensuring a commoner prime minister was elected over a noble from 2010 to 2014. The nobility presented an obvious political target to fire at rather than the reigning monarch.

For a start, the voting bloc of nine out of twenty-six seats exclusively set-aside for noble representatives in the legislature constituted the balance of power because customarily no dissent arose from this bloc. By this, the nobility had a tradition of agreeing to which way they would vote as a collective in the House. Comparatively, among the commoner opposition dissent, disagreement, and crossing the floor to the government's side when voting on parliamentary motions was commonplace.

Difficult to resolve was the political behaviour that played out between the opposition party and its counterparts, the independent people's representatives. More often than not they locked horns in dispute, refusing to compromise and forge any such working alliance. Dispelling the onedimensional Western view that politically the commoner 
members of the Tongan parliament had greater mutual interests than differences, the people's representatives illustrated how divisive and splintered their politics really were. Why was this trend only perceived as detrimental to the country's voting population of forty-five thousand?

In this sense, there was a tremendous tendency to argue that the fragmentation which persisted among the commoner parliamentarians of the Democratic Party and between the Democratic Party and the independent members obstructed democracy, rather than seeing political dissension and divergence as integral to democratic organisation. Critics were wagging the finger at the lack of political homogeneity through unified voting in the House.

They were not tackling the actuality that disagreement and factionalism among politicians representing the commoners was customary for any democratic arrangement, and that in a small island developing state like the Kingdom of Tonga ordinary folk had great difficulty comprehending why disunion prevailed. Democracy, it was thought, would unite the commoners under one voice. Nobody stated before Tonga's 2010 democratisation that the new political system might be chaotic for the Kingdom causing countless divides and disharmonies across society.

To emphasise this point, a split between parliamentarians affiliated to the Friendly Islands' Democratic Party transpired during May and June of 2014 (Latu, 2014a, 2014b). Selecting candidates to stand for Tonga's seventeen constituencies in the November 27th 2014 election stirred in-house conflict. One side of the debate was spoken for by 'Isileli Pulu, the party's deputy chair. Pulu put forward a conservative argument that keeping the same list of candidates in 2014 who had stood in the previous 2010 election was the best policy. 
He thought there was little point in replacing the old party list with new contenders for seats. What if original members tossed out of the party decided to stand as independent candidates and got voted in? The likelihood they might oppose the Democratic Party and vote against their leader in the parliamentary election of the Prime Minister could mean that for a second time in 2014 the party lost the premiership.

If their constituents re-elect them to Parliament in the November [27] election it will backfire on the party as they will become its opponents in the House. We will lose the vote for the premiership and the party will end up in chaos. ('Isileli Pulu cited in Latu, 2014b).

The party leader 'Akilisi Pohiva took a different stand to Pulu which highlighted the political leadership - leader and deputy chair - stood at odds on internal organisational structure. Pohiva reasoned that "a decision on who will stand for the party is still to be made by an independent committee" (Radio New Zealand, 2014c, 2014d). The Democratic Party leader at seventy-three years old proposed a candidate selection system deliberated by a third party who were charged with the responsibility "to come out with justification of why they push one or two candidates, current members, and get people from outside to replace the seats in Parliament" (Radio New Zealand, 2014d).

Highly questionable was how democratic, unbiased, and transparent a selection process carried out by "an independent committee" truly was because the Democratic Party did not disclose the criteria and method for choosing candidates (Radio New Zealand, 2014d). As a committee of three members, "Dr 'Ungatea Kata, Siale Napa'a Fihaki and Tali Makahuniniu" were affiliated to "Tonga's Human Rights and Democracy Movement," which raised criticism from the party's 
deputy chair 'Isileli Pulu as to whether 'Akilisi Pohiva influenced their choice of constituency candidates (Latu, 2014a). What method of redress could disgruntled applicants who missed out on selection use to query the procedure?

"Akilisi Pohiva says it is important that MPs [Members of Parliament] are committed to the party and are people he can work with," reported Radio New Zealand (Radio New Zealand, 2014d). Obviously the party leader was having a spot of bother with parliamentarians who had contested his leadership, thus making themselves people he could no longer work with, to paraphrase his words.

Pohiva's system of hand-picking candidates through a supposed third party resembled a political tactic relieving him from the sole responsibility of shafting three current people's representatives from his candidate list whom he had fallen out with. For the men about to be terminated from standing for the Democratic Party at the 2014 election, Sitiveni Halapua, Semisi Tapueluelu, and Sione Taione, their public silence on the matter was telling. Prior to this division, had they decided to stand down from politics or possibly form political alliances elsewhere?

\section{Double standards}

Niggling at me to write was Guy Powles assertion that "dramatic change has occurred" in Tonga and "the door has been opened" for Western liberal democracy to enter and rule the country. By Powles' verdict, there was one barrier obstructing evolution; "the devolution of executive authority has not been complete" (Powles cited in Garrett, 2014). When in Tonga, as a people's movement from below or as a state directive, was it ever announced that the entirety of executive authority constitutionally afforded the monarch would be plainly and incontestably surrendered to the premier and cabinet? From what sources, exactly, had Powles formed his 
Western-centric opinion, speaking as an older male Pakeha, Palangi (white, European) New Zealander living in Australia?

Typified was a Western predisposition to communicate double standards about how Pacific Island states ought to develop. Publicly Guy Powles recommended Tonga had best hasten the changeover to a Western liberal democracy replicating the developed country exemplar by transferring full executive powers from the reigning monarch to the national executive committee. Melbourne, Australia was the city and country where Powles, an older Pakeha New Zealander male and researcher of constitutional law, had migrated to and permanently resided.

But in today's Australia, democracy as the world governing system was being rejected by a "large number of young Australians" (Oliver, 2014, p. 12). Why was Powles brainwashing Tonga, an overseas developing country he was not a citizen of and did not trace his ethnic descent to, with his democracy fancies when in the very country he lived the younger generation were turning down this political system?

Confirming our previous Poll results, only 60\% of Australian adults, and just 42\% of 18-19 year-olds, say 'democracy is preferable to any other kind of government.' Only a small majority of the population (53\%) choose 'a good democracy' over a 'strong economy.' For those who do not see democracy as the preferable form of government, the strongest reasons are that 'democracy is not working because there is no real difference between the policies of the major parties' (45\% citing this as a major reason) and 'democracy only serves the interests of a few and not the majority of society' (42\%). (Oliver, 2014, p. 3). 
Cited above is Alex Oliver reporting the results of the Lowy Institute Poll for 2014 where she observed that "a surprising aspect of these findings over the years has been the large number of young Australians who reject the view that democracy is preferable to any other kind of government" (Oliver, 2014, p. 12). Why did this stand represent a "surprising" element of Australian political leanings? Could it suggest that a cosmopolitan climate had shaped the younger generation aged 18 to 19 by ideas and practices of global citizenship? As citizens of the world whose access to internet technologies granted them conceptual reach beyond national identity to look attentively at countries and regions, it was plausible that favouring alternatives to democracy signalled that young people had fine-tuned a heightened awareness of political crises transpiring around the globe.

A host of alternative and non-Western media to Radio Australia and Channel 9 gave young Australians selections for acquiring information and forming interpretive views on disruption, chaos, and turmoil in countries such as Afghanistan, Iraq, Libya, Syria, and of late, Ukraine. These were nations of which the Australian foreign affairs department towed the line set down by the United States state department, repeating Washington's whitewash that American-driven military intervention through NATO was protecting the West's security in war torn regions of the Middle East and Eastern Europe. But who aggravated civil war? (Lavrov, 2013, 2014; Oborne, 2013; Switzer, 2014). Could the United States' meddling and intervention in these countries' affairs be singled out as the transgressor, the wrongdoer, and the offender? (Mearsheimer, 2014).

Why would an older generation of Western liberal democracy loyalists expect young Australians under 20 years of age not to criticise their country's double-standard of supporting United States' military aggression in regions of the 
world that America is not geographically located in? By specifying there "is no real difference between the policies of the major [Australian] parties," and that "democracy only serves the interests of a few and not the majority of society," it is conceivable young Australians were acutely aware that peace in the Asia and Pacific regions, the domains closest to Australia, as well as the country's economic advancement was inextricably linked to the way foreign relations and trade were conducted (Oliver, 2014, p. 3). What is more, if policy variation between parties was vague, and democracy persistently repeated the political ambition of obliging politicians' whims mainly by not attending to citizen wellbeing, then logically alternate systems of government from around the world, even from non-Western countries, were worth considering as improved possibilities.

Truly surprising was the Lowy Institute's predisposition to discount human agency as the driver for change. Young Australians similar to young people across the globe possessed and exercised human agency by shifting their views away from democracy as the preferred system of government, and in doing so, clearly demonstrating that they were a different 21 st century generation of political actors to the 20th century era of their parents and grandparents. Concomitant to this, the oldfashioned 20th century rhetoric that democracy represented the best form of government in the world constituted the official stand the New Zealand and Australian governments force-fed to Tonga and Pacific Island states. Sung as their favourite hymn and expressed with zealous, almost religiouslike dedication, it aimed to fully convert the Natives to the Western faith.

Hence, the complicatedness of Tonga's 21st century foreign affairs were undoubtedly compounded by going headto-head with Western development partners, New Zealand, Australia, and America. For the most part, this developed 
country trio were mentally wedged in the 20th century. Last century formed the epoch of world history where America held the financial upper hand over all other countries, even China. It had become a romantic golden age they harked back to, and if the truth be known, desired to re-enact in the current century among the poor country regions such as the Pacific Islands (Matangi Tonga, 2013; Moore, 2014; Poling, 2014; Scarr, 1967; Small, 2014).

However, the New Zealand government proved the most inflexible and wrongheaded, showing an unsavoury habit of acting on its biases and suspicions towards what they imagined the Tongan state had plotted against their control behind closed doors. The New Zealand tactic was a continuous scheming of how to intervene and avert any whiff of Tongan dissent amidst the Western sphere of influence.

An age-old regional policy objective motivated political will. It was all about propping up New Zealand's archaic development mind-set that aid accelerates trade; New Zealand trade not Tongan and Pacific Islands' trade, to be specific. Did aid naturally speed up trade for poor countries? Why were variations to Western liberal democracy, such as the case of Tonga's quasi-democratic system, not accepted by the New Zealand government as authentic, relevant, and realistic for accommodating Tongan civilization and culture?

\section{Aid addicted}

To tackle the aid equals trade conundrum, in Tonga's predicament aid worsened the addiction to aid, and by comparison, trade suffered an agonising demise. Overtly this manifested in the Tu'ivakano government budget submitted yearly to the legislature for approval. Four financial plans for running the country from 2011 to 2015 saw a sharpened 
increase in aid dependency compounded by a decline in national revenue (Radio New Zealand, 2014a, 2014b).

The grand finale budget of the outgoing administration for 2014 to 2015 totalled at “\$483.7 million pa'anga" (Fonua, 2014). Tongan journalist Pesi Fonua reported the sum as a thirty-five per cent increase from the 2013 to 2014 budget, and that the government had upped its need for foreign donations to fifty-nine per cent, including funds from "unconfirmed donors" (Fonua, 2014; Radio New Zealand, 2014a). The fiscal situation conveyed in criticism of state expenditure was that "unconfirmed donors" amounted to unverified cash the national budget was proposing, but really, did not have in hand and was by no means guaranteed of securing in pocket (Fonua, 2014; Radio New Zealand, 2014a).

"Have they gone nuts?" to quote Russian Federation President Vladimir Putin's exclamation about the Kiev junta under Acting President Aleksandr Turchinov and Acting Prime Minister Arseniy Yatsenyuk deploying armed forces into Russian Crimea and Eastern Ukrainian regions of Donetsk, Luhansk, and Odessa to open fire on civilians (Karmanau and Isachenkov, 2014). Despite being an outcry against an entirely different political crisis, Putin's objection, "have they gone nuts?" resonated in social anxiety over the international aid composition of the Tongan state budget. Fifty-nine per cent of monies gathered from overseas assistance was no laughing matter. To the contrary, it was frightening and financially irresponsible.

The Tu'ivakano government had gotten their economic moralities dead wrong, according to Sitiveni Halapua, an opposition people's representative for the Democratic Party. Worrying Halapua was national debt accrued by the EXIM Bank of China loan for $\$ 118$ million pa'anga for the reconstruction of Nuku'alofa after the November 16th 2006 riot destroyed eight per cent of the capital's central business 
district. The current government had sought deferred loan repayments for ten years from China while making payment on the principal interest of $\$ 1$ million pa'anga annually (Brown Pulu, 2011). Still, as Halapua noted, "to reduce" the money owing below forty per cent of national sovereignty, where at present it was sitting slightly under fifty per cent of gross domestic product, would allow for a debt level that was manageable and gave scope "to develop the economy" (Radio New Zealand, 2014b).

I think we have to reduce that level below forty, even if it's thirty per cent that's in my view, more optimal and more sustainable. And that would give us more room to develop the economy. (Sitiveni Halapua cited in Radio New Zealand, 2014b).

Unwittingly Halapua identified the main disconnection in Tongan politics. By speaking up about the budget's unsustainability, he exposed the subject most likely to raise dread, distrust, and disagreement between the opposition party and government. The dismal state of national debt and the economy triggered debate on the one hand, but oddly was the crucial matter continually downplayed, side-lined, and ignored by the head of government.

Throughout four years of Prime Minister Lord Tu'ivakano's term in power, he exhibited a curious habit of disregarding Tonga's financial problems and disengaging from crafting solutions. Rather than dealing with important business at home, it appeared as if the Tongan premier existed in a different world to the desperate living environment ordinary Tongans struggled to survive in. To be concise, apart from frequently travelling overseas with his official entourage, the Prime Minister of Tonga who doubled up as a Tongan noble 
had taken to blogging on the internet for South East Asian media networks.

"On my recent visit to Singapore," began the Prime Minister, "I had the pleasure to participate in a busy programme of events kindly organised for me by the UNDP [United Nations Development Programme] Global Centre for Public Service Excellence." Here Lord Tu'ivakano explained, "My aim in taking part in these activities was to highlight the plight of my small island state while seeking support and advice" (Tu'ivakano, 2014).

It was doubtful Tu'ivakano actually penned this item on the Singapore website, The Strait Times. A likely scenario is that the opinion piece could possibly have been crafted for him by government officials for public relations with the Singapore state. Ironically, the entry politely nodded to the "UN Global Centre for Public Service Excellence” (Tu'ivakano, 2014).

But on the home-front in Tonga, the Prime Minister had met with condemnation from the Public Service Association for allegedly failing to comply with "due process in the appointment of [two] key staff in the Public Service," Mishka Tu'ifua, chair of the public service commission, and acting secretary to the Prime Minister's Office and cabinet, 'Aholotu Palu (Radio New Zealand, 2014e, 2014f).

A relationship breakdown had happened between Tonga's Prime Minister and the Public Service Association, the equivalent of a government employees' union. The Tu'ivakano solution sought to intensify the rift by suing the union in court "for defamation" (Radio New Zealand, 2014e).

According to "Tonga's Public Service Association," the premier was claiming $\$ 10$ thousand pa'anga in damages for a news story published by "Radio New Zealand in March" of 2014 revealing the union had called on his resignation (Radio New Zealand, 2014e). Recapping the headline, the Public Service Association had accused the Prime Minister of illegally 
authorising a government pay-out worth millions to Tongasat, a "communications company partly owned by the sister of King Tupou the 6th, Princess Pilolevu" (Radio New Zealand, 2014e).

\section{New Zealand meddling}

To confound internal politics and pitfalls, resurfacing time and again was New Zealand's wilful attitude not to understand, nor even think about, context-specific circumstances of history and culture which consequently set Tonga apart from convenient moulding into a Western democracy trial product. New Zealand ignited discordant country-to-country communication instead of tempering conflict. Tonga was highly problematic in terms of straightforwardly fitting the stratified system of social and political organization into a democracy archetype copycatting the New Zealand example (Stanford, 2014).

Honestly, the dilemma boiled down to adjusting the Western state of mind fixated on forcing Tonga to bend to its will and patronising advice on ideals of democratic structure. Tonga would not bend; that was an obvious ingredient characterising its political posture. As the New Zealand Prime Minister John Key demonstrated on his two-day visit to Tonga on 4-5 June 2014, inappropriately the New Zealand government could not curtail its meddlesome conduct of political interference in another country's affairs; which if anything, highlighted that they were the regime with a longstanding affliction, not the other way around.

He [the New Zealand Prime Minister] says there will certainly be discussions about Tonga's moves towards full democracy. Mr [John] Key says the power base there is moving but how rapidly it transitions is a matter for the Tongan people. (Stanford, 2014). 
Cropping up in John Key's statement were two tangled factors Tonga had to be weary of, and prepared to deal with. First, the New Zealand Prime Minister presumed that Tonga had made efforts to edge "towards full democracy," but was yet to arrive at the right destination. In a nutshell, Key mimicked Guy Powles' sentiment that democracy in Tonga resembled "unfinished business" (Garrett, 2014). Second, New Zealand foreign affairs had developed an obsessive fascination with Tonga's general election.

Among Tongan citizens it was uttered that the former New Zealand High Commissioner to Tonga during the 2010 election, Jonathan Austin, could hardly contain his excitement on November 25th election day. He was thrilled that 'Akilisi Pohiva's Democratic Party secured the majority of seats for the people's representatives, publicly parading his partiality towards the prospect of Pohiva becoming elected Tonga's prime minister and running the government.

When it did not happen the way he expected and Pohiva was not voted in as the country's premier, the New Zealand High Commissioner's mood was said to have soured, particularly his attitude to the elected Prime Minister Lord Tu'ivakano. Based on interpreting Jonathan Austin's conduct around political elections and politicians, Tongan citizens perceived the New Zealand government to be anti-nobility in parliament and government, and that they viewed Pohiva as Tonga's rightful premier due to him being a commoner as well as the Democratic Party leader.

Whether this portrayed an accurate analysis was not the point. Voters in Tonga's 2010 and 2014 general elections understood the New Zealand government and its citizens held "a core belief that is very strong" (Fanon, 2008). By this, they thought Tonga should have a democratic system of government like theirs, and would not refrain from meddling 
in the country's political affairs until it was a "full democracy" with the nobles' seats abolished from parliament (Stanford, 2014).

In his book Black Skin, White Masks, Frantz Fanon spoke of a social condition "called cognitive dissonance" where an individual or group's "core belief" is resistant to change, even when "presented with evidence that" disproves the belief's validity (Fanon, 2008). Shared circumstances of "cognitive dissonance" seemed wholly applicable to the New Zealand government and New Zealanders in general with opinions about Tonga's political system, including Tongan New Zealanders (Fanon, 2008).

By this I mean collectively this group were certain that "full democracy," meaning the New Zealand system of democracy, was right for Tonga (Stanford, 2014). And despite facts and testimonies of Tongan civilization and culture advising their political structure would not work, was not relevant, and did not have practical application in Tonga, New Zealanders had become intoxicated on their self-importance to the Pacific Islands flatly refusing to see any different.

Sometimes people hold a core belief that is very strong. When they are presented with evidence that works against that belief, the new evidence cannot be accepted. It would create a feeling that is extremely uncomfortable called cognitive dissonance. And because it is so important to protect the core belief, they will rationalize, ignore and even deny anything that doesn't fit in with the core belief. (Fanon, 2008).

\section{Waste of energy}

Of course a similar complaint could be detected in the political behaviour of Tongans, expressly the Tongan state bureaucrats who instructed ministers on government policy, resource 
allocation, and decisions about the country's direction to take to cabinet for rubber-stamp endorsement. In many ways, the characteristic example of Tonga's "cognitive dissonance" was traced to the Tonga Energy Road Map's manoeuvring as an arm of government on the international donor stage in pursuit of development partners (Fanon, 2008).

By definition, a development partner was the United Nations 21st century reference to developed country aid donors and international aid organisations such as Red Cross or OXFAM. However, the recipients of development partnerships understood that Western states bankrolled nongovernment organisations from their countries to do frontline donor work on the ground. What this meant is they did not fund local community service providers, but instead, opted to pay their own citizens redirecting aid dollars back into their national economies.

Returning to the Tonga Energy Road Map (TERM) and its implementation unit which sat under the Prime Minister Lord Tu'ivakano in his foreign affairs and trade portfolio, Lord Ma'afu captured the nature of its management mentality in a ministerial speech. Opening a "capacity building and networking" workshop at the University of the South Pacific Tonga campus from 11 - 13 April 2012, the Minister for Lands, Environment, Climate Change and Natural Resources stated it was "Tonga's best kept secret" (University of the South Pacific, 2012). Perhaps Ma'afu was being satirical. In its national operation, the system by which the Tonga Energy Road Map implementation unit was setting up renewable energy in Tonga came across guarded and hostile.

Considering the Tonga Energy Road Map intended to have fifty per cent of renewable energy sources connected to the national grid by 2020, less than six years from now, it was fathomable why 'Akau'ola, the energy advisor to the Prime Minister Lord Tu'ivakano and the TERM implementation unit 
under the directorship of 'Inoke Vala, was scurrying. To date, the energy road map had constructed two small solar farms; one on Tongatapu, the main island where sixty-five per cent of the total 104,941 population resided; and the other in Vava'u, a northern group of fifty-five islands with a population of 14,922. All up, two photovoltaic plants producing 1.32 megawatts of solar electricity in Tongatapu and 500 kilowatts in Vava'u amounted to around five per cent of the national energy source (Sustainable Energy for All, 2014; Meridian, 2014). The remaining ninety-plus per cent of Tonga's electricity was diesel generated and reliant on imported crude oil.

It was 'Akau'ola who persuaded the Prime Minister Lord Tu'ivakano to ditch all other development priorities and focus solely on renewable energy as his pet project for Tonga. Hence, the reason why accelerating agricultural trade for small-scale Tongan farmers was removed from the head of government's list of desired outcomes for his four-year term at the helm. Was this decision grounded in a prudent evaluation of Tonga's fragmented and uncoordinated development industries?

Working across sectors towards a big picture vision of national development necessitated public buy-in to modelling community partnerships with state agencies so that villages and organisations collaborated with the bureaucracy. But the troubling psychology was that routinely the Tongan state did not value its citizens as equal associates in public service affairs. Did government and community partnerships ever really happen? Or was it about appealing to overseas donor dollars through paper-only-policy by play-acting partnerships that did not eventuate in any measurable way meaningful to communities on the ground?

Alternatively, could the real story be that racking up renewable energy as Tonga's stand-alone development 
objective resulted from cut-throat politics? In one ear was the energy advisor coaching the Prime Minister on what to think and how to act, while at the core of government's day-to-day operation were eleven cabinet ministers' rivalling for a sizeable cut of the state budget to advance their ministries' policies. Inescapably in this political mix, there was bound to be a head-on collision of development drives, willpowers, and wants.

'Akau'ola illustrated this point in his discussion to the Sustainable Energy for All Forum held at the United Nations New York headquarters on June 4th 2014. Highlighting the role of the Prime Minister Lord Tu'ivakano as Tonga's driver for acquiring renewable energy, 'Akau'ola answered his own question, "what specifically does the leader have to do" to make that happen? ('Akau'ola, 2014).

What specifically does the leader have to do? Well, whenever he meets with any of the development partners associated with assisting that country or state, he usually has on his wish list four or five priorities. Just as the development partners that he's meeting with have four or five priorities. So, how do we make sure energy remains as one of the, at least say the top two? Basically what you've got to do is remove the four, the other four or other three from his list. So, that's why it's important that he himself or she decide that this is a national priority and is a priority that we implement it as quickly as possible. ('Akau'ola, 2014).

Eliminating development partners' goals on their "wish list" by forcing renewable energy as Tonga's core business observably had become the political tactic 'Akau'ola advised Prime Minister Lord Tu'ivakano to adopt in negotiations with developed country donors, banks, and international aid 
organisations ('Akau'ola, 2014). The great pity was the premier's reluctance to seek well-thought-out information and credible expertise beyond an insular, inward looking circle of Tongan advisors, friends, and family members. By the nature of their relationship closeness to, and familiarity with, the head of government, the Tongan Prime Minister's in-house supporters were demonstrably blind to their own biases, prejudices, and shortfalls.

The truth was access to clean drinking water sustained human survival on the Kingdom of Tonga's 36 out of 176 inhabited coral atolls where all underground water sources were vulnerable to infiltration by rising sea levels. Salt water contamination of fresh water effectually destroyed drinking water, food crops, and human life; end of story, end of history (United Nations, 2014). The life threatening questions were therefore two-fold. Could Tongans survive without the entire population gaining access to electricity, specifically renewable energy? Yes, was the correct answer. Comparably, was survival in Tonga viable without access to clean drinking water? No, was the common sense answer.

Sustainable water never made it on the Tongan Prime Minister's development "wish list" for his country of coral atolls susceptible to limited safe water, drought, and the risk of saline contamination to underground supplies ('Akau'ola, 2014). Importantly, the mutually dependent relationship between clean water and energy was paramount to human security and endurance for small island developing states. In his foreword to The United Nations World Water Development Report 2014 Secretary-General to the United Nations Ban Kimoon stressed an integral connection between water and energy was a central contributor to human and economic development. 
Water and energy are inextricably linked. Water is essential for the production, distribution and use of energy. Energy is crucial for the extraction and delivery of safe drinking water - and for the very safety of water itself. People everywhere - but especially the most vulnerable and marginalized - face great risks when access to either is limited or compromised. (Ban Ki-moon cited in United Nations, 2014, p. iv).

'Asipele Palaki, the secretary for Tonga's Ministry of Lands, Environment, Climate Change and Natural Resources, whose minister was Lord Ma'afu, identified a critical factor at the inaugural 2011 government retreat in Neiafu, Vava'u for ministers, chief executive officers, and development partners (Government of Tonga, 2011). Renewable energy made no practical sense as the country's one-off goal which development industries were to solely base, coordinate, plan, and put into action their respective policies and services. It had to be assented to by sectors as one of their multiple business objectives, which by no means said it was the most significant to their individual industry's development.

Forcing the Tonga Energy Road Map as a stand-alone renewable energy implementation unit on government stakeholders because the Prime Minister fancied it should be done immediately by recommendation of his energy advisor exposed a management technique in disastrous leadership. Lord Ma'afu's secretary therefore impressed a straightforward point on participants at the 2011 Government of Tonga retreat: All sectors considered themselves integral to the country's economic and social advancement, whether that be water, energy, telecommunications, agriculture, fisheries, infrastructure, transport, commercial business, or a host of other industries that created both services and jobs for Tongan citizens. 
The environmentally sensitive method for systematising a national development strategy was not to privilege renewable energy above competing priorities. Contrariwise, it was smarter for renewable energy to function in a coordinated, negotiated, and equitable fashion, partnering with other sectors to avoid diverting constrained income, particularly funds acquired from international donors and bank grants, to a single sector project that achieved marginal outcomes.

Four years on at the end of the Tu'ivakano regime, 'Asipele Palaki's sentiments had come true. Clean energy was the underperformer, and any prospect of synchronised national development had turned into an expectable and predictable failure. Was this avoidable? Yes, if the Tongan premier had demonstrated a willingness to listen to, and consider the value of, different accounts to the single storyline he was told.

The Prime Minister himself, Lord Tu'ivakano, had little option but to admit publicly that " 54 million US dollars" of renewable energy projects amounted to nil effect on lowering the cost of household electricity in Tonga (Radio New Zealand, 2014a).

The Prime Minister, Lord Tu'ivakano says the government's multi-million dollar assistance to reduce electricity tariffs appears to have had no impact on bills. Radio Tonga reports the Prime Minister telling Parliament that despite several solar projects in place, there has still been a hike in electricity costs. (Radio New Zealand, 2014a).

The premier's half-baked testimony to parliament on June 16th 2014 avowed he would bring in the International Renewable Energy Agency (IRENA) based in Abu Dhabi to scrutinise Tonga Power Limited's book keeping. Possibly, the Prime Minister's energy advisor was in his ear suggesting the 
problem lay with the "financial management and administration" of the government-owned power company (Radio New Zealand, 2014a). But the hitch of cutting down the price of power was a tad more complicated than basically replacing fossil fuel dependence with solar and wind generated electricity. It was the how that confounded an otherwise simple solution; how are electricity prices stabilised in the transition from utilising one energy source to another?

On February 6th 2014 at the commencement of Tonga's third solar farm project in Vaini, the principal village on the estate of Lord Ma'afu, the chair of Tonga Power Limited board of trustees Carl Sanft emphasised that it was difficult to fix the price of power. Hence, the greatest challenge besetting the national electricity supply was constructing "solar farms" in the face of rising electricity costs (Tora, 2014).

Board Chairman Mr Carl Sanft said TPL [Tonga Power Limited] faced a big challenge at the moment as the development of solar farms continues "even when the cost of electricity" continues to rise. (Tora, 2014).

Renewable energy was a small supplementary source integrated into a national electricity supply dominated by 95 percent fossil fuel consumption. As the cost of importing fossil fuels and producing diesel-generated electricity hiked up, a total of 5 percent renewable energy did absolutely nothing to reduce price increases. Renewable energy merely acted as a complementary power source, which was environmentally cleaner.

To purchase, maintain, and upgrade renewable energy technology, which modified quickly in terms of technological advancement, was expensive. The infrastructure set-up was plain pricey, requiring large capital investment. However, the real catch was that although solar and wind energy had the 
potential to "lower wholesale electricity prices because creating renewable energy once the infrastructure is in place is relatively cheap, that benefit does not necessarily extend to the consumer" (Australian Broadcasting Corporation, 2014b).

And so it happened in Tonga's predicament, there were no consumer benefits to having renewable energy sources. Producing solar power at a cheaper rate did not reduce household electricity bills. If any such savings were made by Tonga Power Limited with a marginal renewable energy source of 5 percent, then it was absorbed into making up for the overall cost of the national electricity supply.

Drilling down to the bone of contention when it came to public assessment of the Prime Minister's statements, politics, and overall performance, Lord Tu'ivakano was persistently criticised for being distant and detached from Tongan citizens and everyday quandaries affecting ordinary people's lives. Condemnation was crystal clear: Tonga's premier had a narrow fixation on renewable energy, and courting development partners and banks for donations. Unfavourably, he spent too little time on problem-solving how to create jobs, which would go some way to curbing the difficulties of material survival in Tonga; hardships that were increasingly going off right under his nose.

\section{Huntington's clash of civilizations}

Tonga was never assimilated into a Western sphere of influence, especially New Zealand's realm of Pacific Island territories, the Cook Islands, Niue, and Tokelau to begin with, which posed a basic tension triggering tremors and fall-outs in the Tonga and New Zealand foreign relationship. Did consecutive New Zealand governments ever truly get this? The short answer was no, definitely not.

For some hazy reason the heterogeneity and diversity of South Pacific states, in particular the island groupings of 
Polynesia, escaped the New Zealand political consciousness which preferred to pretend Polynesians were alike, or quite possibly all the same by skin-colour, physical phenotype, linguistic similarity, hierarchical organisation, human nature, and poor country predicament. In today's politics, this glaring and somewhat racist inaccuracy was consequential of the John Key government's attention-seeking stunt to prove itself to the United States Barack Obama administration that New Zealand was the Pacific regional leader who knew how to control Pacific Island states, and would guarantee the Polynesian sub-region, in particular, remained unwaveringly pro-West (Lieven and Hulsman, 2006).

Tonga was turning out to be challenging in the Polynesian cluster of countries. It was not singly the orientation to China and the East that was worrisome, but more that the Tongan state was starting to unpack a suitcase of cultural justifications for its distinctiveness from traditional Western development partners. The cultural argument was tricky to delimit and debunk. It charged off into the unchartered territory of power and knowledge, criticising the New Zealand and Australian governments for naturally assuming that because they had economic might, they also had the right to define knowledge over and about Tonga.

Who were these foreigners, and what claims to knowledge defining and confining were they championing under whose authority? Playing out in a sub-domain of the Pacific Islands region, south of the equator, was the clash of Tongan civilization with Western development partners. Therefore, how did the affirmation of Tongan civilization as the organisational attitude of the sovereign state reveal itself as symptomatic of international geopolitics going off in other regions of the world?

Consequently, media had become embroiled in culture wars through the mere mimicry and repetition of state 
narratives invented by their own governments, whether Western or non-Western. In noting that, what methods did public consumers use to make collective sense of conflicting news stories on the politics directly shaping foreign relations between countries in their regions?

For the most part, this essay undrapes two mutually linked occurrences that situate Tonga in the global landscape of swelling interconnectedness between countries and regions. First of all, as Tonga's self-styled democracy took hold, the state's confidence grew to defend its individuality as a unique civilization with well-defined cultural practices. In brief, culture counted as well as countered the Westernization of state and society. This constructed a perplexing predicament; Tongans might have wanted to democratise but not necessarily Westernize in the process. Secondly, as the rifts between Tonga and New Zealand amplified, it was not exclusively due to Tonga inclining to a China-dominated Asian sphere of influence.

Truthfully, New Zealand did not competently appreciate and understand the South Pacific region it professed to be part of, and claimed as its sphere of influence. Tonga and other independent Pacific Island states did not see their history couched within Western civilization, despite European and United States territorial expansion in the late 19th and early 20th centuries. Hence, their history was non-Western and so too was the propensity to empathise with non-Western states and regions, especially their political battles in confronting Western and global governance dictates over lives, livelihoods, and living environments.

First, differences among civilizations are not only real; they are basic. Civilizations are differentiated from each other by history, language, culture, tradition and, most important, religion. The people of different 
civilizations have different views on the relations between God and man, the individual and the group, the citizen and the state, parents and children, husband and wife, as well as differing views of the relative importance of rights and responsibilities, liberty and authority, equality and hierarchy. These differences are the product of centuries. They will not soon disappear. They are far more fundamental than differences among political ideologies and political regimes. Differences do not necessarily mean conflict, and conflict does not necessarily mean violence. (Huntington, 1993, p. 25).

Cited above, Samuel Huntington could have been writing about Tonga. But in 1993 when his article The Clash of Civilizations? first appeared in the summer edition of Foreign Policy, which was four years before he authored his book The Clash of Civilizations and the Remaking of World Order, he was not referring to ancient civilisations of the Pacific Islands region at all (Huntington, 1993, 1997). In fact, the Pacific was not considered in his analysis of how culture and civilization clashes were reconfiguring the world, and in the process, repainting history by brushstrokes that were not American or Western European. The islands of the world's largest ocean were too small and insignificant to be classed seriously as civilizations of old, despite the fact that this classification, in reality, captured how they understood their histories, cultures, languages, and belief systems.

Understandably as an American political scientist, Huntington's interests focused on the emergence of a new world order that would come after the 1991 collapse of the Soviet Union of Socialist Republics (USSR). At once, he saw that the ideological warfare between competing political systems of Western liberal democracy and socialism, or more precisely, soviet-style communism, had ended. 
Such a stance had been foreshadowed by Francis Fukuyama, another American political scientist, in his 1992 book titled The End of History and the Last Man (Fukuyama, 1992).

What we may be witnessing is not just the end of the Cold War, or the passing of a particular period of postwar history, but the end of history as such: that is, the end point of mankind's ideological evolution and the universalization of Western liberal democracy as the final form of human government. The triumph of the West, of the Western idea, is evident first of all in the total exhaustion of viable systematic alternatives to Western liberalism. (Fukuyama, 1992).

Fukuyama was right in a one sense; the ideal of Western liberal democracy as the prevailing form of government had swept over the world in a little more than a century. But Huntington pushed the inquiry further by proposing that in the 21 st century, culture as a product of civilization was to become the contested identity site across the globe. The irony was that in this age of globalization in which the world had shrunk and Americanised consumer tastes overrode, and in some cases cancelled out local culture, cultural identity politics proliferated. Civilizations of peoples and places who considered themselves non-Western multiplied under protest against the American and Western European superiority complex, a self-perpetuating doctrine which connoted they ruled the world and wrote history. The counter narrative presented an explicit critique of historical power structures: whose world history was this, and for whose political and financial gains had it served?

Huntington's main argument was that because "these differences" between the West and non-Western civilizations 
were "the product of centuries," they were deep-rooted in the human psyche of culture and therefore would "not soon disappear." Being "far more fundamental than differences among political ideologies and political regimes" the "clash of civilizations," as he put it, would not singly endure but multiply. However, this did not mean an all-out-fight repartitioning the contemporary world into the West versus the rest would be the inevitable consequence, despite the historical fact that "differences among civilizations have generated the most prolonged and the most violent conflicts" (Huntington, 1993, p. 25).

If anything, Huntington alluded to 21 st century strains and stresses between the world's most important civilizations and their regional spheres of influence. Undoubtedly the global condition was complicated to grasp in a simplistic narrative devised by American and Western European collusion (Lavelle, 2014a, 2014b, 2014c, 2014d). There was, of course, United Nations global governance authorising onesize-fits-all rulings on mending cultural rifts. Grafted to its side was the North Atlantic Treaty Organization (NATO) policing a fertile Western imagination of world conflict by militarily acting to safeguard America's unipolar power.

Global governance and NATO expansion proffered Western prescribed remedies for ills that the United States inflicted on countries to grasp on to its primacy as the world's only military and economic superpower. The burning queries were firstly, had the United Nations and NATO outlived its 20th century purpose, relevance, and efficacy? And if so, how would a multipolar new world order unfold in the 21 st century whereby the BRICS alliance of Brazil, Russia, India, China, and South Africa gained economic parity and political clout with the old West of America and Western Europe? 


\section{Media culture wars}

Brazilian journalist Pepe Escobar, a foreign correspondent for the Asia Times on Asian and Middle Eastern politics outlined the instrumental role that media misreporting played. Painting a distorted picture of reality "to Western publics in general" created what has been described as an Orwellian environment of information wars (Escobar, 2014). Here, two media branches were polarised on the international frontline of news reporting. There were networks owned and operated by Western corporations parroting American political propaganda channelled from President Obama's Whitehouse administration and endorsed by the European Union headquarters in Brussels. And there were the counter networks challenging Western indoctrination by asserting alternative points of difference sympathetic to non-Western centres of regional power such as the Russian Federation and China for Eurasia.

As expected, the media branch which human consciousness gravitated to was dependent on culture. Culture was the human reference point. Culture was the moral compass used to read a preferred media map on the Clash of Civilizations, and see truth-value in the narrative's meaning (Huntington, 1993). Culture was both a tool of inclusion mirroring collective tastes, canons, values, and doctrines on humanity and power relations, as well as a systematic method of exclusion setting them and their kind apart from us. They were different. They thought, spoke, wrote, and behaved differently to us. And there was no site more convenient and accessible to download and digest their preconceptions of, and intolerances to us, than internet media.

At that intersection where two types of cultural talk crossover, rebuke each other, and part ways, it was easy to judge them back with a predisposition to culture similar in its loyalty to what they had historically, and conventionally to this 
day, paraded in their biases, prejudices, and discriminations. The site of contestation, therefore, was not about fighting over universal rights to truth-telling. Instead, debates and disagreements adopted a hyper-capitalist form. Market competition was about which side could bankroll the technology and resources required to grow consumer audiences in their sphere of influence, which similar to geopolitics were located in regions; that is, inside the homebases or homeland states from where corporate media expanded its operation outward, staging an international setup. Consumption rates were therefore determined by business consistency at pitching key messages that convincingly sold and resold information to niche markets, which if large enough in number, reflected mass groupings affiliated to mutual civilizations and cultural identities. In the end, the market was the winner, not the sides playing goodies and baddies in web space.

Commenting on the Thailand military coup that took place on Thursday 22 May 2014 ousting Prime Minister Yingluck Shinawatra's government, Escobar averred the political circumstances were "much more complicated than" the simplistic Western media portrayal of "Bangkok elites against the poor in the countryside" (Escobar, 2014). Army and coup leader General Prayuth Chan-ocha maintained that "the coup was necessary to restore law and order, and bring peace to the kingdom through dialogue, reforms, and eventually, new elections" (Samuels, 2014).

As expected the military junta's take on "dialogue, reforms, and new elections" diverged from a Western understanding of political procedure underpinning a liberal democracy, which was the point Escobar impressed. How can an outsider, a Western observer, a non-Thai with no experience of living and working inside this constitutional monarchy's sovereign territory of sixty-seven million people make a precise 
judgement of what is essentially going on here? The short answer is they cannot, and do not, as detected in faulty and flimsy media accounts by Westerners manufactured especially for the palate, taste, and sensitivity of their kind (Escobar, 2014).

The way Thailand is depicted to Western publics in general, we have the Bangkok elites against the poor in the countryside. It's much more complicated than that. You have different strands among the Bangkok elites. You have monarchists; you have the military as well; you have business interests, diverging business interests. Then we have the fight against this clan and different clans in Bangkok. You have the urban elites, especially in Bangkok, privileging I would say a sort of monarchist military solution, which is not the same thing. And you have these masses in the countryside who revere [the former prime minister from 2001 to 2006] Thaksin [Shinawatra] because for the first time they had some voice and even their standard of living got much better under Thaksin. So it's extremely complicated to explain this in two or three minutes. (Escobar, 2014).

Escobar's gesturing that American and Western European media opted for a convenient storyline that stubbornly concealed complicated political terrain in non-Western states was an argument advanced by German journalist Manuel Ochsenreiter on the present day Ukraine crisis as it unravelled. The disconcerting pattern of Western media misreporting, as Oschenreiter pointed out, had a two decade history when it came to news coverage of Ukrainian politics and society. Over a course of twenty years a "lack of understanding of history, national identity, cultural identity, [and] religious identity" on Western media's part, compounded 
by a wilful neglect to correct mangled reports produced on Ukraine, were now entrenched as the standard method for how regular news was fed to consumers (Lavelle, 2014c).

Yes, we have to see also another problem. We have to see that the Western mainstream media, how were they reporting the last twenty years about Ukraine? And when you check those reports you will see that there's one red line going through all those reports, and that this is the complete lack of understanding; the lack of understanding of history; lack of understanding of national identity, cultural identity, religious identity, very important values for the people. But Western mainstream media did something what is somehow expected by let me call it, it's [a] sort of new liberal, postmodernist catalogue of values given by US [United States] liberals that they say all these things like identity, like history, like religion, don't play anymore role. (Manuel Ochsenreiter cited in Lavelle, 2014c).

Ochsenreiter blamed an overarching "postmodernist" ideology framing a "catalogue of values given by United States liberals" for misreading the importance of "identity, history, [and] religion" in today's international relations (Lavelle, 2014c). Falsely, "postmodernist" thinking assumed "all these things" did not figure in how contemporary states and citizens defined themselves in relation to others, particularly in the forging of regional cooperation and identity (Lavelle, 2014c).

But it did matter, as Ochsenreiter argued; it mattered to the point that identity grounded in history and religion, a corresponding reference to civilization and culture, was the most important and misunderstood factor causing geopolitical disputes between states and their associated groupings. Ochsenreiter based his argument on the United States and the 
European Union versus the Russian Federation and its Eurasian allies, including China, locked in disagreement over who was culpable for escalating the Ukrainian crisis into a full-blown civil war between the country's Western and Eastern regions, governing bodies, and peoples.

Still on the subject of the Ukrainian crisis, Russian journalist Dmitry Babich analysed the United States and European Union's obsession with elections as the salve for patching up political schisms and cracks. Babich argued that certain states, such as Ukraine and Iraq, where America had taken it upon themselves to intervene in the country's democracy by forcibly removing an elected President, were by no means homogeneous in identity, ethnicity, culture, language, and history. The setback was that not only did American interventionists misunderstand this, but they also clutched onto misplaced faith in that holding national elections "in the midst of a civil war" would create representative parliaments. Misguidedly, it was thought all the trouble of political sectarianism and factionalism would magically disappear once an election was held and citizens voted. America's morbid fascination with elections as the beall-end-all problem fixer of Western liberal democracy glitches in non-Western states was dead wrong. Worse than that, the United States state department was incapable of seeing why their thinking and actions had failed dismally.

The problem is the presidential election won't solve anything because first it won't be held in Donetsk and Luhansk which make up 14 per cent of the Ukrainian electorate. And second, even if it's held there people are not going to be satisfied with a choice between Petro Poroshenko, a nationalist, and Yulia Tymoshenko, a nationalist and a manipulator. This is the choice that people all over Ukraine will be given. But the Western 
media keeps making the same mistake; we have seen it in Iraq. Just remember how the US [United States] media was upbeat about elections in Iraq in the midst of a civil war in that country. They said that, oh yes, now we have that Shiite Sunni thing; hundreds of people die every day, they blow each other up. But there will be an election. The Shiite will get their share in the parliament. The Sunnis will get their share. And things will settle down. Of course that didn't happen. And it's not going to happen now. But the [Western] media keeps sort of saying what the bosses want the United States government]. And the bosses want to be optimistic. They want to believe; they have this almost religious belief in elections and courts and in so-called human rights in the way they understand it. (Dmitry Babich cited in Lavelle, 2014c).

Babich explained, on the one hand, an "almost religious belief in elections and courts and in so-called human rights in the way they understand it" drove American cultural values, tastes, preferences, and canons to go forth and dominate the world (Lavelle, 2014c). Pepe Escobar, on the other, made it known that underneath the neo-colonial, militaristic, interventionist actions of America in Syria and Ukraine, the "Anglo American elites [were] terrified that they don't monopolise information wars anymore" (Lavelle, 2014b).

Escobar spoke truthfully. Culture wars had played out in the media's fight to control information, and the fact that the American government in cahoots with the European Union's Brussels, London, and Paris triangulated base did not "monopolise information" broadcasted to the world culminated in power loss (Lavelle, 2014b). Representing non-American media were cultural competitors with a global reach based in Moscow, China, Bonn Doha, and a host of non-United States 
cities. Broadcasting and publishing in languages other than English was non-American media's trademark. Not only did multiple language broadcasting stand and act for "global opinion," but it contested English language media from completely ruling over the most popular sites for receiving news and information - internet, television, and social media.

It's the Anglo American elites terrified that they don't monopolise information wars anymore. This means that if you go to a hotel room in Karachi or in Dubai, you don't have only the BBC [British Broadcasting Corporation] and CNN [Cable News Network] anymore. You have RT [Russia Today]. You have CCTV9. You have Deutsch Welle. You have Al Jazeera. It's the multipolar information world that has surfaced, and obviously the narrative which used to be controlled by the Anglo American media until a few years ago; now we have RT telling the story in Syria, telling the story in Ukraine. And obviously we have John Kerry accusing RT of bullhorn propaganda; of course because the Fox News is not; CNN is not; New York Times and the Washington Post are not of course. This is very complicated because finally, we are watching the emergence of global public opinion, not only in English but in different languages, telling a narrative that is completely different from the one manufactured by the Ministry of Truth, which happens to be located between Washington, New York, and Brussels with an extension to London and Paris sometimes. That for me is the biggest difference and it's going to be from now on. (Pepe Escobar cited in Lavelle, 2014b).

Challenging and overturning Washington's single narrative propagated as truth, which in turn, was marketed by American corporate media, as Escobar pointed out, had 
caused "the biggest difference" reshaping news and information that consumers located in every country witnessed and experienced first-hand (Lavelle, 2014b). Disputing American news stories that made the United States government out to be the good guys combating non-American evil around the world had become a global phenomenon of our current times.

\section{Trapped in the cold war}

United States foreign policy under President Barack Obama had flopped horribly, upping the frequency of wars and civilian deaths in foreign countries by American drones, missiles, and armed forces than previous bloodshed spilled by the George W. Bush government. Democrats and Republicans overwhelmingly concurred on a contentious point in modern American history: Obama had no control over the United States state department's reckless and destructive miscalculations on how to carry out international relations.

Part of the problem were the perilous blind spots in Washington's foreign policy narrative, which American media giants sold on the global market. The danger was the United States government flunked at analysing political situations; in particular, the transformational power shift its closest ally, the European Union, had undergone. The 22nd to 25th May 2014 elections for the European parliament saw "thirty per cent of far right parties" voted in (Lavelle, 2014a). Washington declined to comment as if the growing voter popularity of extreme nationalist parties in the European Union had never happened.

For the United States, this self-proclaimed most powerful country in the world based the Obama administration's foreign policy on America's exceptionalism; that is, its belief that America's primacy was indispensable to world order (Mearsheimer, 2014). Notably then, what were the 
consequences of ignoring the facts on the ground? David Speedie, a Scottish academic and director of the United States global engagement program at the Carnegie Council in New York, spoke candidly about the European parliament elections.

On an institutional basis, Anatol Lieven in London described the EU [European Union] policy toward this whole Ukraine crisis as toothless megalomania. In other words, they want to exert control but they really don't have any authority of gravitas to do it. But bear in mind one other thing; we've just had elections across Europe where in some countries almost thirty per cent of far right parties were elected to the European parliament. This is a very sinister development that's not completely disassociated from what's going on in Ukraine right now. I think we are looking at a far right backlash across Europe and including Ukraine that we have to be very, very mindful of. And of course Graham [Phillips] in London will know only too well about this; you know, UKIP [United Kingdom Independence Party], the Front National in France. These are shady people to say the very least and there are connections, they talk to each other, they argue, but they also conspire. We have a series of events going on across the European continent right now that are very, very troubling. (David Speedie cited in Lavelle, 2014a).

Was the United States government attuned to the "series of events going on across the European continent right now that are very, very troubling?" (Lavelle, 2014a). Of course not, and why would they be? America had no history in the European continent. It was not a country of Europe; nor did it promote 
itself as a European culture and identity. Lastly and most significantly, America was not part of Europe's geography.

Truthfully, America was not about exporting greater democratic freedoms and human rights to the European continent. The United States government had smugly propped up an interim government in Kiev, Ukraine, which came to power during the 23rd to the 26th of February 2014. Overthrowing a democratically elected president and forming alliances with far right parties using brute violence, intimidation, and destruction to property as the political means to an ends, did not dissuade America from believing the Kiev junta regime was the legitimate ruler of Ukraine's ethnically, culturally, and linguistically diverse regions (Al Jazeera, 2014; BBC, 2014). Additionally, the United States government had backed a Ukrainian presidential election on May 25th 2014 "in the midst of a civil war" and carnage between the West and East regions of Ukraine. Washington swore this represented a fair and free democratic election for all Ukrainians, despite the fact that Eastern Ukraine would not participate (Lavelle, 2014c).

What was America really after? Power, was the clear-cut answer. Moreover, why was Ukraine instrumental to advancing America's plug for dominance in a region it did not historically, culturally, and geographically belong to? Largely because the United States state department figured it could manipulate West Ukrainian anti-Russia politics to expand NATO forces on Russia's territorial border, thus, geopolitically and economically fracturing and isolating Russia from European states.

The Obama administration had exhausted its foreign policy repertoire and run out of ideas. Pitifully, the United States government was locked in a cold war mentality where it sought to force an out-of-date containment policy on the Russian Federation, imagining the Kremlin to be Washington's 
arch enemy. The cold hard truth was 20th century American foreign policy was redundant in the 21 st century, and this collapsing unipolar superpower had not defrosted its frozen state of mind to grasp the new world order had switched to multipolar international relations, but to its disadvantage and the detriment of others, the United States had not.

It is here that I will wrap up the three sections on the clash of civilizations, media culture wars, and faulty American foreign policy, with a memoir from Serhii Plokhy, a professor of Ukrainian history now resident in the United States. Plokhy reminisced about his initial encounter with teaching Ukraine's independence after the 1991 collapse of the Soviet Union to American college students. Advised by the history faculty at a particular United States university to instruct a course on the "triumph of democracy in Moscow" Plokhy protested, querying what would he know about this subject "coming from Ukraine?" (Plokhy, 2014).

According to Plokhy, the "mobilization of national identity" constituted the crucial inquiry into the Ukrainian case of statehood, sovereignty, and political independence (Plokhy, 2014). Condescendingly, he was told by his American colleagues, "this is not important" (Plokhy, 2014). Who defines importance - a Ukrainian professor who studies his country's history and national identity, or his fellow American academics at the university where he is employed?

Let's teach about democracy and triumph of democracy in Moscow. I said I am coming from Ukraine. What I know? And my perspective is very different. It's not about triumph of democracy. This is about mobilization of national identity. They said no, who is interested in nations? Who is interested in the republics? This is not important. I said well, that's the only course I can teach. (Plokhy, 2014). 


\section{Ignoring culture as a political system}

Questioning who defines importance in big picture terms of "global security issues such as Ukraine," requires to some extent fathoming the Obama regime's faltering geopolitics and diplomacy in respect of engaging and disengaging with the Russian Federation. Such bungling foreign policy provided an American model of political disaster on which New Zealand chose to fashion its relationship with the Pacific Island states (White House, 2014; Beehive, 2014; Aotearoa, 2014; Poling, 2014; TVNZ, 2014).

Under John Key's leadership, the New Zealand government desired the role of favourite lapdog to the United States. In fact, New Zealand was desperate to be preferred by Washington over its Australian counterpart, Tony Abbott's government prompting John Key to eagerly assent to the Obama regime's rebalancing act in the Asia Pacific region without critically contemplating the long term consequences.

How did "the U.S. rebalance to the Asia-Pacific region" translate into foreign intervention? (White House, 2014). For overlapping territorial disputes in the South China Seas between China, Taiwan, Japan, Vietnam, Brunei, Malaysia, and the Philippines, it involved an increased American navy presence which based itself in Tokyo, Japan, a Western ally looking to militarise under Prime Minister Shinzo Abe. Contrastingly, for Pacific Island states such as Tonga, it entailed deeper economic dependency on development partners. New Zealand therefore intended to play an intensified role to outflank China's sway and hang onto the Pacific Islands, especially Polynesia, as a Western domain.

President Obama will welcome New Zealand Prime Minister John Key back to the White House on June 20, 
2014. The meeting will highlight our increasingly close relationship with New Zealand and our collaboration on the Trans-Pacific Partnership, climate change, and military-to-military cooperation. The President looks forward to consulting with Prime Minister Key on these and other issues, including the U.S. rebalance to the Asia-Pacific region, regional maritime security issues, and global security issues such as Ukraine. (White House, 2014).

New Zealand's Prime Minister could be said suffered from a chronic condition of short sightedness and single mindedness. He coveted free trade through the Trans Pacific Partnership plus a seat on the United Nations Security Council, and was willing to follow along unquestioningly with any unscrupulous wheeling and dealing America proposed.

John Key's government amended the Government Communications Security Bureau Act in 2013 strengthening the regime's capability to share foreign intelligence on other governments, specifically Pacific Island governments, with its Five Eyes collaborators who were the United States, the United Kingdom, Canada, and Australia under the United Kingdom and United States of America Agreement of 1946. A multilateral agreement to collaborate on intelligence operations, the Five Eyes alliance was, and still is, responsible for spying on foreign governments as well as its own citizens.

The trouble with John Key was that he put his country's hand up to the United States as the best pick over Australia to wield clout and respect with Pacific Island states. Supposedly, New Zealand would bring them into line as a steadfast Western geopolitical domain. His scheming never took hold over Tonga for two mutually related reasons, which were reinforced by the fact that New Zealand's propensity to enter into secret trade and intelligence agreements with America and 
its Western allies proved it was not a Pacific Island nation, or a trustworthy and transparent friend. New Zealand masqueraded as a quasi-Pacific nation of sorts, while reality revealed its loyalty was to commercial business, and colluding with its own kind who definitely were not the small island developing states of the Pacific Ocean.

Exacerbating tension with Tonga was first and foremost, the New Zealand government did not respect and value culture as a political system; nor did it see that a modern democracy could be steered, sculpted, and shaped by a culture rooted in national identity. Culture was separated out from politics creating a dualism between the two where they were perceived as irreconcilable concepts and practices. In New Zealand, public culture for Pasifika peoples was confined to annual events such as the Auckland Pasifika Festival and Samoan language week, while politics was defined by the secular, irreligious practice of state bureaucracy through public administration and policy. The two did not meet, marry up, and produce a hybrid offspring named democracy which looked and behaved like a Tongan-ised, culturalised, Christianised, political system. The glaring truth was Tonga had gone and done exactly that.

Second, and entangled in the first point, the New Zealand government talked up economic development in Pacific Island states, but acted contrarily to safeguard the status quo and preserve an imbalance of trade between New Zealand and Pacific Island states. Tonga understood that New Zealand's exporting of free trade policies to the South Pacific came with a high-cost, and that the price of trade liberalism amounted to New Zealand and Australia consolidating their supremacy as the region's developed economies by exploiting and dominating poor Pacific Island states for their own commercial benefit. 


\section{Regionalization as de-globalization}

Tu'ivakano: China was like the new guy around the block. When we look at Small Island Developing States they are friends with everybody and no enemy. They like to help in order to develop so China is able to provide some of this help to assist even when we look at these buildings developed here, they have a large amount of money that can assist us.

If we can compare to the two other commercial banks, they have very high interest of 10-15 percent; nobody in Tonga would loan from the banks because there are other costs affecting them. If China can provide that for us I would not say no. I would take it and rebuild, otherwise we won't have what is happening now. It's the same as New Zealand helping us in all aspects of our development and they have always been there for us all the time.

At the moment some Chinese run retail shops which helps our economy. It's sad that some of our Tongans when they run small shops they don't have the skills to keep the books and they run for two months and shop closes. I say learn from them because they have been in business for centuries. (Prime Minister Lord Tu'ivakano cited in Folau, 2014).

"The new guy around the block" was causing relationship tensions for Tonga and New Zealand. China had deprioritised their bilateral affair making New Zealand green-eyed and possessive of Tonga (Folau, 2014). New Zealand felt it had known Tonga much longer than China, ever since it was a 19th century settler colony of the British Empire, and even the Prime Minister Lord Tu'ivakano admitted openly "they have always been there for us [New Zealand] all of the time" (Folau, 2014). It stung to be dumped for "the new guy around the 
block," especially when the one doing the dumping was a developing country of coloured Natives on coral atolls who collectively, as a nation, were flat broke and did not have any money (Folau, 2014).

The New Zealand government felt used and bruised for their aid donations, prestige, and influence in the region. And New Zealand media indiscriminately backed its government, reporting that Prime Minister John Key had warned Tonga that New Zealand aid "doesn't bail out loans that you might take from another nationality. As long as you are comfortable with that and as long as your lenders are comfortable then that's fine" (Small, 2014). The other "nationality" was nonWestern, and unlike America's International Monetary Fund and the World Bank, in New Zealand's eyes had moved in on their turf, and was obstructing their monopoly over Pacific Island states as the preferred development partner.

Of course New Zealand newspapers and television were poking at Tonga taking out soft loans from China; in particular, the $\$ 118$ million pa'anga loan from the EXIM Bank of China used to rebuild the Nuku'alofa central business district after eighty per cent of buildings and properties were burnt, vandalised, destroyed, and looted in the riot of November 16th 2006. The complex factors triggering the riot were never sufficiently analysed by media or academic research, which generally put it down to civil unrest exerted against the Tongan government's sluggishness under the Feleti Sevele administration to amend the 1875 constitution democratising the state. Eight years on in 2014, the Tongan state was struggling to make loan repayments, labelled by the Asian Development Bank's economic forecasts as suffering from debt distress.

The exact problem of the matter for New Zealand was spikier than what media concocted and cordoned off as the truth. Pragmatically, the region was getting reconfigured and 
it was uncertain at this time whether New Zealand would be left in on conditions delimiting its membership and participation, or moved out altogether of the new regional identity arrangement. Fiji was the country loosening the grip of New Zealand and Australia to their self-appointed and selfserving leadership of Pacific Island states.

By formalising the Pacific Islands Development Forum and its Suva secretariat in 2013, Fiji had exposed structural cracks in the 43 year old conventional Pacific Islands Forum. The traditional forum looked incapable of reinventing itself to tackle development dilemmas. Grappling to adjust a high-level bureaucrat mentality to working with civil society and the business sector to achieve results on the ground written into its Pacific Plan, perhaps the aging, somewhat cumbersome Pacific Islands Forum had passed its use-by date.

Identified by the Fiji led Pacific Islands Development Forum was that to an overpowering degree, New Zealand and Australia's predominance of defining regionalism at the Pacific Islands Forum obstructed Pacific Island states from being independent, exercising sovereignty, cooperating among themselves, combining forces and resources, and seeking out non-Western development partners. The big brother developed states played Orwellian politics, watching over the peripheral poor states, and punishing dissenters whom they believed contravened group rules defined and interpreted by them alone without consulting subordinate members. Changing the rules to the advantage of Pacific Island countries and not their Western neighbours perched on the Pacific Rim gave rise to regional identity with purposeful political ambition, which essentially meant inaugurating a counter forum excluding New Zealand and Australia's membership.

Expectedly, scepticism surfaced from Australian and New Zealand commentators and reporters about the Pacific Islands Development Forum's prowess and longevity. Was this 
financially sustainable, and if so, where would the investment come from? Did the secretariat have a viable work plan, or was it an annual Pacific Islands talk-fest with an odd mix of countries - Indonesia, Morocco, Venezuela, Israel, Singapore, Kazakhstan, Kuwait, Georgia, France, and Australia - in attendance as observers?

Lastly, as Jenny Hayward-Jones of the Lowy Institute observed, the Pacific Islands Development Forum might have offered an alternative model to the Pacific Islands Forum. But did that make it the preferred regional body of Pacific Island countries? Hayward-Jones was doubtful.

And now that we've heard Fiji say that it won't rejoin the Pacific Islands Forum unless Australia and New Zealand exit the Pacific Islands Forum, it certainly seems to be sending a big signal that they prefer to have a forum on their own terms; and to send a signal that this forum is called the Pacific Islands Development Forum and they want it to run the way it's suggested. So I think they are putting a big stake out there to say this is our bid, and it's run on our terms, and we'd like this to be the primary regional forum, and whether they'll convince other Pacific Island countries remains to be seen. I think they've got a long way to go there. (Hayward-Jones and Newton Cain, 2014).

Disbelief that the Pacific Islands Development Forum would be durable enough to become a permanent fixture, a possible architect of regionalism, and an undermining force to New Zealand and Australia's primacy at the Pacific Islands Forum was the anticipated reaction. Hayward-Jones' exclamation that "it certainly seems to be sending a big signal that they prefer to have a forum on their own terms," said more about her identity position as a white Australian woman 
analysing the Natives. Her surprise at the audaciousness of small islands "sending a big signal" was obvious. Verifiable information about the Native subject, the nuts and bolts of the organisation's governance structure, comments from Pacific Islanders in attendance, dialogical exchanges between countries, never made her mind-map.

In his opening address at Nadi, Fiji on 19 June 2014, Fijian Prime Minister Frank Bainimarama who chaired the Pacific Islands Development Forum's government council as the host country set the record straight. He stressed the regional body had instituted "a proper governance structure" with "a senior officials committee, a government council, and a work programme and budget." The secretariat headquarters in Suva, Fiji and "an interim secretary general" were established. Also, there were definite "terms of agreement for [the forum's] long term institutional arrangement, and a host country agreement." An organising principle was founded on green economies, as well as including civil society and businesses in dialogue, information sharing, and influencing the decision making of the government council.

The Pacific Islands Development Forum, our grand coalition of regional governments, civil society organisations, and the private sector. We especially welcome those representatives who have found a voice in the PIDF [Pacific Islands Development Forum] for the first time, having been excluded from the governments only Pacific Islands Forum where they come from the private sector, the highly valued generator of jobs in our economies, or civil society organisations of all kinds. Your voices are the genuine voices of the grassroots in our Pacific societies. For you represent the ordinary men and women whose welfare must always be upmost in 
our minds and whom we are all here to serve. (Australian Broadcasting Corporation, 2014a).

Did this allure the buy-in of the twelve Pacific Island states who attended? The answer from the Tongan Prime Minister's Office was affirmative.

This year's Summit will be an opportunity for Tonga and other Leaders of the Pacific to explore how they can move to the next level in their desire to create resilient sustainable futures for their people and genuine partnerships for green growth. Since its inception in 2013, the PIDF [Pacific Islands Development Forum] has been a unique platform that brings together leaders from the public and private sectors and civil society to address regional development challenges. It also recognised that partnership is a critical mechanism for implementing sustainable development and enhancing international cooperation. (Prime Minister's Office, 2014).

Fiji and Tonga's relationship had been awkward during Bainimarama and Tu'ivakano's terms as prime minister for their respective countries. At times, it had gotten point-blank quarrelsome because of their ocean boundaries overlapping in delimiting their competing outer continental shelf claims in the Lau-Colville Ridge to the United Nations Commission on the Limits of the Continental Shelf (Brown Pulu, 2014). In saying this, had New Zealand and Australian commentators on the Pacific Islands Development Forum made light of complex factors and by doing so, underestimated the gravitas of a Fiji and Tonga alliance?

Tonga had a Prime Minister, Lord Tu'ivakano, whose kinship ties and political aspirations were closer to Fiji than the toothless and tokenistic Polynesian Leaders Group led by 
Samoa's Prime Minister Tuilaepa Malielegaoi. Fiji had a President, Epeli Nailatikau, who maintained familial ties to his high-ranking Tongan relatives. And then there was Ma'afu, Tonga's senior noble and Minister for Lands and Environment whose connections to Fiji bridged chiefly, military, and political networks. If any Polynesian state was independent enough to cross boundaries and align their national development policies with Fiji, member states of the Melanesian Spearhead Group, and the Pacific Islands Development Forum, it was definitely Tonga.

A critical inquiry emerged. If Fiji and Tonga were to join forces to pursue their national strategies in correlation with the new regional identity proposed by the Pacific Islands Development Forum, one which omitted New Zealand and Australia, could that enhance the likelihood of success? The unthinkable, the inconceivable, the unimaginable, might then become possible. Centrally, if Fiji and Tonga backed the Pacific Islands Development Forum as the first-choice regional body for Pacific Island states, would this secure the buy-in of all Pacific Island states? If so, there was greater prospect for a competing centre of power to materialise in the 21 st century. Pacific Islands' regionalism would have acquired the scope and reach to reposition further towards China, the East, and nonWestern development partners, subverting in the 21 st century what historically has been a Western sphere of influence.

At the global level of international relations, critics recognised that neoconservatives had taken over American foreign policy, entrenching the Obama administration in continuous military interventions which did not deescalate sectarianism in countries, but spiralled into civil wars. The concept and practice of neo-conservatism in the South Pacific, however, was not wholly relevant or applicable to New Zealand and Australia's mode of operation in wielding power in regional affairs. Pertinent here, was the notion of neo-colonialism as a 
system of political and economic actions which reinvented dominant and subordinate power relations, likened to the colonial era of Western European empires.

To recap, for Pacific Island states, global politics represented the comeback of neo-colonial power where New Zealand and Australia held small island developing states in a throat-hold by dominating trade relationships with no intention of alleviating poverty by trade equity. Put simply, the Pacific Rim countries refused to import agricultural and fisheries products from Pacific Island states at rates that near matched the total exports they traded in the region. Propelling economic injustice was the logic that if Pacific Island states remained aid dependent, they were easier to contain under a Western domain. Encouraging trade competitiveness triggered a risk that they might see themselves as equal to the West, and in turn, seek bargaining power and political leverage on par with New Zealand and Australia.

Russian foreign minister Sergey Lavrov analysed the significance of what he termed the "regionalization of global politics" (Lavrov, 2009). Nowadays, when global governance, namely the United Nations as a form of world parliament, fails to adequately identify, let alone settle causal factors of "conflicts and crisis situations" in various regions, the regions can and do take matters into their own hands. Thus, "regionalization" is a method of counteracting the incompetency of "global politics" to sort out regional matters by "deglobalization" (Lavrov, 2009). In short, it is the turning away from global governance for practical purposes, which involve countries banding together in a regional alliance to prevent conflict from erupting and splitting them up.

Related to this is the regionalization of global politics, which means several phenomena at once. In particular, we are talking about finding regional solutions to conflicts 
and crisis situations. On the other hand, the strengthening of regional-level management in an environment where the global mechanisms do not work serves as a safety net in case of development of processes of "deglobalization," ensuring that the fragmentation does not go deeper, where each state would defend itself against all others. (Lavrov, 2009).

Written in 2009, deglobalization as an analytical frame could be used to rationalise how to avert "fragmentation" between countries in war torn regions such as the Middle East (Lavrov, 2009). Then again, the principle of solving our own problems as a collective of countries with more in common than in difference had functional applicability across wideranging troubles that regions face.

For the Pacific Islands Development Forum, "regionalization" was conceptualised through the mutual goal to minimise the devastation of climate change on living environments (Lavrov, 2009). Endorsed as the pressing development dilemma constricting Pacific Island states and societies, sustaining life and livelihoods in island homelands necessitated greening local economies at a regional scale. From the outset, neutralising climate change by practising sustainable development measures became the region's identity brand which the Pacific Islands Development Forum took on.

Conversely, the dual driving force behind regional identity was independence and self-determination. Pacific Island states representing the Pacific Islands Development Forum were firstly, non-aligned with New Zealand and Australia and secondly, autonomous and self-directed decision makers as a regional body. Epitomising this vision in his closing speech at the second forum in Nadi, Fiji on 20 June 2014, Fiji Prime Minister Frank Bainimarama stressed "the fact that for the 
first time, we all have a genuinely Pacific gathering" (Xinhua, 2014). "Genuinely Pacific" alluded to one identity shift: Finally, there was a Pacific Islands regional forum for Pacific Island states only, free of New Zealand and Australia's intrusion, interference, and involvement.

The inclusiveness of the meeting is a great strength. Part of the attraction of the PIDF [Pacific Islands Development Forum] is still its novelty value; the fact that for the first time, we all have a genuinely Pacific gathering that is also genuinely inclusive - Governments, civil society organizations and business working together to forge a sustainable development path for us all. (Xinhua, 2014).

In 2013, the Preambular Declaration adopted by Pacific Island states making up the Pacific Islands Development Forum unambiguously stated its overarching objective for the region as, "Our Region to Develop and Our Region to Own" (Pacific Islands Development Forum, 2013, p. 6). Regional development equated to ownership in the sense that member states to the forum represented, spoke for, decided, and carried out the business of regional development on behalf of their countries and citizens. Under the umbrella organisation, regional polity integrated "identity" as a central creed for affiliation.

Clearly stated, the forum "safeguards its unique cultural diversity, spirituality and identity." Cultural justification was given in that "we embrace our identity and are proud of our diverse cultures and values" (Pacific Islands Development Forum 2013, p. 6).

PREAMBULAR DECLARATION

Our Region to Develop and Our Region to Own 
1. This is Our Forum. As Pacific Islanders in dialogue and partnership with the International Community and with each other, we are interdependent and strive to live in harmony with our environment, forming a cornerstone of our identity and binding our far flung region into a coherent whole.

2. This is Our Development Path. Our path builds, nurtures and defends a Pacific that is progressive in improving the wellbeing of its people, safeguards its unique cultural diversity, spirituality and identity.

3. This is Our Future. We embrace our identity and are proud of our diverse cultures and values. We are good stewards of our people, our resources and our ecosystems. We envision a Pacific that is mature, confident and focused on its strategic strengths and led by visionary and transformative leaders. (Pacific Islands Development Forum, 2013, p. 6).

The declaration doctrine, "Our Forum, Our Development Path, Our Future, echoed and evoked an unmistakeable indigenous philosophy reclaiming regional identity and country-to-country relations for Pacific Islanders, principally (Pacific Islands Development Forum, 2013, p. 6). By no means did the orientation and testimonial to "Our Region" add in New Zealand and Australia as settler countries located on the Pacific Rim on historical grounds. Traditionally, they were Palangi (white, European) colonial administrations of Pacific Island states before the era of post-1960s political independence, and in today's regional economy were largely looked upon as neo-colonialists operating as traders and aid donors, who traded excessively more than they assisted.

In light of shifting Pacific Island states towards "Our Region," one that limited, if not precluded New Zealand and Australia planting and positioning themselves as the centre of 
power, forging development partnerships with non-Western states was essential to maintaining momentum. At one level, new trade avenues and aid donors were needed to subdue the extensiveness of the New Zealand and Australian governments' infiltration and intervention in Pacific regional affairs. Overstating the reference to islands in naming the Pacific Islands Development Forum was a conscious effort to reclaim polity and power for the islanders, not the Westerners.

By cultural measurement, non-Western development partnerships were favourable to envisaging "regionalization" and "de-Westernization" as emphasised in the Pacific Islands Development Forum declaration that, "we embrace our identity and are proud of our diverse cultures and values" (Lavrov, 2009; Pacific Islands Development Forum, 2013, p. 6). Concisely, in the case of the Russian Federation as an emerging non-Western power, the striking difference between their attitude and the West's was political recognition.

Russian diplomacy recognised its state responsibility "to understand better the needs and interests of these island countries," and operated prudently and respectfully as a visitor and outsider (Lavrov, 2012b). By no uncertain means did the Russian Federation arrogantly assume like New Zealand, Australia, and America, that they knew all about Pacific Islanders better than they knew themselves, and were therefore entitled as the powerful to tell the pitiable what was best for them.

We [the Russian Federation] consider the Pacific region as one of the key players of the Russian foreign policy given that it's important in world economy, world finances, and world politics; and given its importance as well from the point of view of security; not only regional but global security. The key players are located here. And in promoting the dialogue between those key players 
in the formats like APEC [Asia-Pacific Economic Cooperation], East Asia summits [ASEAN, Association of Southeast Asian Nations], IUCN regional forum [International Union for the Conservation of Nature], we cannot and should not ignore the fact that there are island developing countries who are not participating in that process; who are not part of those formats. And my visit here can really help me and help the Russian Federation to understand better the needs and interests of these island countries. (Lavrov, 2012b).

"We cannot and should not ignore the fact that there are island developing countries who are not participating in that process; who are not part of those formats," said Russian foreign minister Sergey Lavrov (Lavrov, 2012b). His closing remarks were made during a state visit to Fiji in February of 2012. To an audience of government leaders from the Pacific Islands, Lavrov's sentiments sided with a swelling push for Pacific owned "regionalization" (Lavrov, 2009). Conveying empathy and understanding for "the needs and interests of these island countries" he had met for the first time was above and beyond New Zealand, Australia, and New Zealand's combined skill, knowledge, and diplomatic capacity (Lavrov, $2012 b)$. If this summed up high-level diplomacy reciprocated by non-Western development partners in a nutshell, then why would the Fiji led Pacific Islands Development Forum not want to engineer close, cordial, and corresponding relations? (Lavrov, 2012a).

"Regionalization" and "deglobalization" as mutually related political approaches to strengthening regional identity among Pacific Island states manifested in the interpersonal communication style of Pacific politicians and statesmen (Lavrov, 2009). As a form of "de-Westernization," Huntington explained that elites of non-Western countries had gone full 
circle (Huntington, 1993, p. 27). No longer aspiring to beliefs acquired from overseas Western education, de-Westernized elites had returned to indigenous cultural values and practices of their homeland states. What did this mean exactly when contemplating the de-Westernized Tongan statesman?

\section{The de-Westernized Tongan statesman}

I finally don't care

There is nothing fancy

in what I say

\section{P. K. Harmon}

Lord Ma'afu ditched the speech typed on a sheet of paper he placed in front of himself at a table of international panellists. Representing the Government of Tonga, he was seated alongside Fiji and Belize government officials, and staff of the World Bank, the International Renewable Energy Agency, and Federation Internationale de L'Automobile (FIA Foundation). This was a side event to commemorate World Environment Day at the inaugural Sustainable Energy for All Forum on June 5th 2014 hosted by the United Nations headquarters in Manhattan, New York. Organised and facilitated by Elliot Harris of the United Nations Environment Programme (UNEP), the panel theme was Small Island Developing States and Clean Energy.

Televised live on UN WEB TV, Ma'afu spontaneously decided to go for broke, a Hawaiian colloquial expression which meant he wagered everything on the few minutes he had in hand. Delivering an ad lib performance, he spoke from his heart, off the top of his head. An impromptu speech, not read off paper, was an unconventional style for an invited panellist giving out information on behalf of their government 
to a United Nations forum. But still, he held the floor. Captivatedly, the audience hung on his every word enunciated in crisp, clear, carefully crafted English he had learned over forty years ago as a schoolboy of Wanganui Collegiate, a private boarding school in New Zealand.

To this day he retained his posh-sounding Kiwi brogue, a dead giveaway to New Zealanders he was ex-Wanganui Collegiate, an elite establishment for students from the wealthier classes. Being a former Collegiate schoolboy was Ma'afu's New Zealand identity marker, and one that allowed him to network at ease on behalf of the Tongan government with New Zealand ministers, diplomats, bureaucrats, consultants, and business owners either resident in, or visiting Tonga.

In public relations he exhibited private school manners, civility, and breeding, and was renowned among the Palangi (European, white) community in Nuku'alofa, Tonga as a gentleman of the upper class with appropriated New Zealand values and speech. Palangi people took to Ma'afu immediately, finding him a highly likeable man of his word, one who was sincere, down to earth, and trustworthy.

Ma'afu's lived experience had made him an enigma. At one level he was a member of the Tongan elite, a high-ranking noble who had received a privileged private school education in New Zealand. He spoke English effortlessly as if it was his mother tongue. With no difficulty, he mixed among the Palangi community, a distinct grouping who ran successful businesses in Tonga as ex-patriate New Zealanders and Australians. He enjoyed a dual-place in the Tongan upper class as well as with the Palangi ex-patriates.

But there was no doubt that he was a staunch Tongan loyalist. Time had progressed from his youthful days when the only Tongans educated overseas at expensive boarding schools were royalty and nobility, along with half-casts from European 
trader families who had wealth. So too, had Ma'afu moved forward. His country's battle was realising political and economic independence as a sovereign state, while at the same time, resisting against being owned, operated, and manipulated by the International Monetary Fund, the World Bank, the Asian Development Bank, the EXIM Bank of China, and an invading horde of aid donors all wanting something of Tonga in return.

In public life, being subjected to an unstable climate where Pacific regional politics were bogged down by New Zealand and Australia's oversized egos and in Tonga's situation, government resistance to New Zealand's bullying - all compounded by merciless politics - had groomed Ma'afu to function, analyse, and problem-solve as a "de-Westernized and indigenized" Tongan statesman (Huntington, 1993, p. 27). To explain this point, Samuel Huntington penned it best.

In the past, the elites of non-Western societies were usually the people who were most involved with the West, had been educated at Oxford, the Sorbonne or Sandhurst, and had absorbed Western attitudes and values. At the same time, the populace in non-Western countries often remained deeply imbued with the indigenous culture. Now, however, these relationships are being reversed. A de-Westernization and indigenization of elites is occurring in many non-Western countries at the same time that Western, usually American, cultures, styles and habits become more popular among the mass of people. (Huntington, 1993, pp. 26-27).

Jestingly, I wrote Ma'afu at the sustainable energy forum in New York: "Aren't you glad your father paid your boarding school fees to attend Wanganui Collegiate?" But really, we 
both knew it was his charismatic personality and passion for Tonga, his national homeland, his people and place in the Pacific Ocean, which carried him well in the world. Being confident and competent to speak with clarity of thought in Western settings, dialogues, meetings, and conferences was a skill-set he had acquired and made his trademark.

However, what propelled him to think outside the square; to question power, knowledge, and resource disparities between Western development partners and his kind, the "non-Western countries;" to speak honestly about difficult matters to the most difficult people to work with, including his own people running the government; came down to culture and identity (Huntington, 1993, p. 27). He was a Tongan noble. No matter how fluently he travelled in Western contexts, he was not Palangi. His allegiance and obligations would always be to serving his own country and citizens who were ethnic Tongan nationals. This principle for Ma'afu, remained non-negotiable and permanently fixed to his heartstrings.

To contextualise Ma'afu's dialogue at the Small Island States and Clean Energy panel, it is important to note that he stood in as a replacement speaker for the Prime Minister Lord Tu'ivakano. As the head of Foreign Affairs and Trade and the chair of the Tonga Energy Road Map Committee, the premier was the correct minister to attend the United Nations sustainable energy forum. It was his ministry, not Ma'afu's, which housed the Tonga Energy Road Map implementation unit that 'Akau'ola was advisor to. Tu'ivakano had amalgamated energy into his foreign affairs portfolio. He was also the one minister out of eleven constituting Tonga's cabinet who had direct access to what the Tonga Energy Road Map implementation unit was actually doing on a day-to-day basis to attain the country's clean energy objective of 50 per cent renewable sources by 2020 . 
Therefore, why was Ma'afu in attendance for Prime Minister Tu'ivakano? Conceivably, New Zealand Prime Minister John Key's two-day visit to Tonga on 3 - 5 June clashed with the Sustainable Energy for All Forum held at the United Nations New York headquarters from 4 - 6 June 2014. The Tongan Prime Minister's Office released a press statement that "Prime Minister Key will hold high-level discussions on key areas to advance economic and social cooperation, including renewable energy, which is a priority for the Government and is supported by the New Zealand Aid Programme" (Prime Minister's Offfice, 2014).

Whether renewable energy formed the "priority" talking point of the New Zealand Prime Minister's core business in Tonga was doubtful (Prime Minister's Office, 2014). What the Tongan government press release did highlight was that more than likely, Tu'ivakano would try out his strong-arming strategy on the talk table with John Key; that is, the coercion tactic that 'Akau'ola spelled out in his discussion at the sustainable energy forum on 4 June 2014.

So, how do we make sure energy remains as one of the, at least say the top two? Basically what you've got to do is remove the four [priorities], the other four or other three from his list. ('Akau'ola, 2014).

Subsequent to this, the ministerial membership of the Tonga Energy Road Map Committee comprised of the Prime Minister as chair, Lord Ma'afu for Lands, Environment, Climate Change and Natural Resources as alternate chair, and the Minister for Finance and National Planning. Understandably then, the Prime Minister expected Ma'afu to represent him at the Sustainable Energy for All Forum in his role as alternate chair. Moreover, given the Prime Minister's foreign affairs focus was about getting renewable energy 
projects funded and built by development partners, he was responsible for Tonga's consistent attendance at high-level international forums.

Preceding the Sustainable Energy for All Forum in June of 2014 was the first Asian and Pacific Energy Forum (APEF) organised by the United Nations Economic and Social Commission for Asia and the Pacific (ESCAP). Hosted by the Russian Federation in Vladivostok from 27 - 30 May 2013, the organising theme was "energy security" as "an important prerequisite for development” (United Nations ESCAP, 2013). At this event, Prime Minister Lord Tu'ivakano headed the Pacific Islands delegation as the region's lead speaker because the political ambition of the Tonga Energy Road Map implementation unit was to host the second Asian and Pacific Energy Forum (APEF) set for 2018.

When Tonga was chosen by the United Nations as the host country for the 2018 Asian and Pacific Energy Forum, the Tonga Energy Road Map website publicised its cultural belief that this is "not an entirely unexpected result. In fact, it is a very Tongan result" (Tonga Energy Road Map, 2013). What constituted "a very Tongan result," and how did it differ from a very non-Tongan result? (Tonga Energy Road Map, 2013). If the Prime Minister of Tonga's bid had been rejected, would that make it a very non-Tongan result?

My point is that tangled up in hosting pitches, and appearances at every renewable energy event organised by the United Nations, were convictions and creeds about Tongan culture. Suspiciously, culture for the purpose of acquiring renewable energy was manufactured by the few running the Tonga Energy Road Map implementation unit, without any buy-in from below, from the poor Tongan citizens who theoretically were to become developed by solar and wind energy. 
For those who have been following the Prime Minister and the work of TERM-C [Tonga Energy Road Map Committee], which includes amongst its members, Lord Ma'afu as alternate chair and the Minister for Finance and National Planning ... the [United Nations] selection of Tonga as host of the next APEF [Asia Pacific Energy Forum] meeting [in 2018] is perhaps not an entirely unexpected result. In fact, it is a very Tongan result, given Tonga's other roles as member of the Council of the UAE-based [United Arab Emirates] International Renewable Energy Agency, IRENA, and founding member of the recently constituted Global Renewable Energy Club. (Tonga Energy Road Map, 2013).

For Ma'afu, however, being put in as a substitute speaker meant he had to thoughtfully get his key messages across at the United Nations Sustainable Energy for All Forum in a way that was meaningful and relevant to his ministerial responsibilities. Firstly, he held the Tongan government portfolio for environment and climate change, not energy. Concentrating on the 2014 World Environment Day theme, raise your voice, he detailed the living environment of the small island developing state he came from in the Pacific Ocean. Thus, his thoughts were framed by an inquiry. Fundamentally, what is the Tongan understanding of living under climate change conditions? Subtly underpinning this, how is clean energy being pursued in Tonga's circumstance?

Secondly, Ma'afu opted to unfold a deeply personal narrative about shared experience, the culture of everyday life in relation to climate change for Pacific Islanders. It was a topic he could speak to experientially and eloquently, while posing a rhetorical question: "If there is such a thing" as 100 per cent renewable energy, then would that stop climate change in Tonga? (United Nations, 2014a). Plainly the answer 
was no, it would not, which wedged open a host of unspoken variables as to why not. The lasting impression he conveyed was that under fatalistic circumstances not of their own making, Tongans and other Pacific Islanders were vulnerable, but also wilful and hopeful that their small atolls would remain, and so too, might they.

Ma'afu: $\quad$ As it's been mentioned before, the fifth of June is the World Environment Day which is marked worldwide. This year's theme is raise your voice, climate is changing. To me, it is appropriate and timely that we have a common theme like this because it concerns [itself] a lot to the island states because we have a lot in common.

We can physically see the adverse effect of climate change in our island nations. We can see the coastal erosion, sea level rise that claims the low lying areas; that also affects the underground water supply. The droughts are getting severe. Ladies and gentlemen, the hurricanes are getting stronger and stronger every year.

We normally have a cyclone season which is roughly from December to April. Now, that has changed. It's from January to December. And all we could do is pray that we don't have a severe hurricane like that this year. Unfortunately, Tonga got hit by a cyclone early this year which was in category five; which completely destroyed over 85 per cent of all households in the northern groups. It gives you an idea, ladies and gentlemen, that small island states have so much in common in terms of the environment.

I would like to touch a wee bit on energy. Energy's a funny little guy. It's the major factor which concerns and affects climate change, and at the same time it contributes to the mitigation measures in terms of clean 
energy. Almost 95 per cent of small island states rely heavily on fossil fuels as sources of energy, including us from the Pacific.

What is clean energy? I suppose if you ask me I would define clean energy as renewable energy. The Pacific Island region's initiative to promote renewable energy [involves] ministerial dialogue, Pacific leaders' summit, road maps, civil programmes, and projects in the region; and those are just some of the programmes I've mentioned.

Most of the regions actually have a target, and objectives, and a timeline to accomplish these missions. In Tonga, we have a national target of 50 per cent renewable energy by 2020, and a hundred per cent beyond 2020 if there is such a thing; and it clearly states [this] in our Tonga energy road map. And currently, we're working for our targets of implementing various programmes on renewable energy under this Tonga energy road map. (United Nations, 2014a).

Sefita Hao'uli, a Tongan broadcaster based in Auckland, New Zealand contemplated Ma'afu's dialogue. The minister's rhetorical probing of renewable energy targets, and how it was possible to accurately measure percentages and fractions against a tide of climate change impacts which had radically transformed lives, livelihoods, and living environments appealed to Sefita. In this sense, Ma'afu had accomplished what he set out to do. His critical insights contained his own people's anxiety and disquiet, which he had given voice to at a United Nations talk-fest; the United Nations, a world parliament where historically, Pacific Islanders were noted in proceedings by others who had power over them, rather than speaking as, and speaking for, themselves. 
Sefita Hao'uli: I think that Ma'afu's rhetorical. If there is such a thing (as 100 percent clean energy) is an interesting page to turn. The answer is of course no, there isn't such a thing so the 50 percent clean energy concept is a figment. 50 percent of what? But we will stay with the 50 percent which has been plucked out of thin air. We can now move to own more of the moral high ground by asking that the rest of the industrialised world (the developed countries) answer one question: Now that we're 50 percent clean energy and still paying the price [of climate change], when will you be 50 percent clean energy?

There is a very good case to make for refusing to go any further than 50 because in the bigger scheme of things, we could go 150 percent (when Ma'afu asks if there's such a thing, he may as well say if there's such a thing as 100 percent we may as well be 150 percent while we're at it), and as long as China burns coal, and Obama plays around with the coal industries in the US [United States], and Fonterra suppliers turn pine forests into paddocks, climate change will be here to stay. (Hao'uli, 2014).

\section{King George Tupou V}

George Tupou V: I think it's a natural development of the original 19th century constitution. It's an attempt to take the principles of that constitution and apply them in 21st century idiom which of course has to be democracy.

Bruce Hill:

Is this something that you particularly support?

George Tupou V: Yes, yes I've always wanted to do this for the country and it's a very practical idea of 
political life has to travel at the same speed, at the same level as the development of our economic life.

Bruce Hill: Is Tonga ready for this kind of more representative system do you think?

George Tupou V: $\quad I$ believe so because for the past 150 years we've had very democratic institutions, namely the churches. Like the Christian church in Western Europe, even during the middle ages, these are probably the only truly democratic institutions which have existed in the country. For example, church affairs are discussed freely by the members who elect their officials, bishops, and presidents. And it's the one of the institutions in Tonga where a person of reasonably humble beginnings can rise to a position of great power and influence by his own talents without aristocratic patronage.

Bruce Hill: What happens to your role as monarch under this new system? Are your powers diminished or decreased, or simply changed?

George Tupou V: Officially the sovereign's powers remain unchanged because we are a monarchy we have a unity of power as opposed to a separation of power. The difference in the future is that I shall not be able to exercise any of my powers at will. All the sovereign's powers must be exercised solely on the advice of the prime minister in most things, and in judicial matters, the law lords who advise the exercise of power. In that case I suppose, we are different from other nominal monarchies which retain the trappings of monarchy but actually govern themselves as republics.

Bruce Hill: Historically kings have resisted diminution of their powers. Why do you think this is the way to go? 
George Tupou V: Well like others of my generation, my education has generally been a liberal European education and I feel sure that without a European education, with a solely Tongan education, I don't believe I would have been able to make these changes.

Bruce Hill: The events of 2006 when a prodemocracy rally got out of hand and there was rioting and burning and looting and much of the central business district of Nuku'alofa was destroyed; what role did that event play in getting this kind of political change? Did it speed things up? Or was this change going to happen now anyway?

George Tupou V: There were changes; I think the changes would have happened anyway. But what the riots did for me, it vindicated my belief in the systems approach to change which was compartmentalizing each stage of the revolution, and putting each stage under the charge or tutelage of different groups in society and in government.

Bruce Hill: After seeing the destruction of what's called 16/11 did you feel under more pressure to move towards this change?

George Tupou V: I didn't feel under pressure from below. But the pressure I felt was the pressure not to change which was exerted on me from my own class in society.

Bruce Hill: $\quad$ What form did that pressure take?

George Tupou V: $\quad$ People expressed to me their views, my fellow nobility expressed me their views that perhaps Tonga was better off as it was before under the old system. Well I had a very simple answer to that, and that was you can't expect to keep repeating the same 
mistakes and expect a different result because that would be totally unreasonable.

Bruce Hill: $\quad$ Tonga is a very traditional kind of a system and the role of the monarchy's very, very important in society. Will this political change lead to a change in the relationship between you and the Tongan people?

George Tupou V: I don't believe so. The relationship between the monarchy in Tonga and the people is one of blood and indeed with the nobility as well. In that every Tongan; there's a Tongan phrase that literally means every Tongan has a road to the palace, which means that if you go back far enough in your ancestry you can find that you're related to this nobleman or that one, or even to the king. In the past, the basis for this relationship has been one relative speaking to another. That's how they felt about it.

Bruce Hill: Is this new system ideal as it is? Or do you think there might be some more change further down the road?

George Tupou V: Well what we've done is that we've given it our best shot and said this is a model that we've come up with, that's the present government and I. But I hope that in the future if the government or the parliament find that what we've put up, what we've proposed is inadequate in any way, that they'll feel free to make the necessary adjustments. It's not an unchangeable thing. I think our constitution should be kept alive with minor changes and adjustments to suit life as the country progresses. (Bruce Hill, 2010).

\section{Tonga was never Western}

The 2010 Radio Australia interview cited above between the late King George Tupou V of Tonga and Australian journalist 
Bruce Hill is one of the few publicly accessible historical archives where the monarch's words can be transcribed verbatim, read, contextualised, and analysed. However, the transcript seldom, if ever, is referenced, cited, or commented on in research publications and political opinions about Tonga's democratic transition.

By comparison, often featured in academic and journalism works are secondary sources interpreting a speaker's viewpoint on an original conversation or event that occurred in relation to democracy hiccups. The slant is observably proWestern in the sense that a New Zealand, Australian, or American evaluation of how democracy has to be carried out is the standard measurement which Tonga unsurprisingly falls short of.

American diplomacy expounded by Larry Dinger, the former United States ambassador based in Suva, Fiji, harboured a one-eyed view that the Tongan monarchy would be put in a political headlock; a situation where conceding to limited executive authority presented the only pathway forward to democracy. Dinger, like his New Zealand and Australian counterparts, had failed to grasp the Tongan historical and cultural context in which politics played out. Narrowly, he was fanatical about democracy as his American mind experienced and understood it in the United States, as opposed to Tonga.

Tonga's trials and tribulations were never really about getting full democracy of the Western liberal sort. It was always about power sharing. How could power sharing reasonably work without collapsing the structure - the monarchy and the nobility - under whose social power and prestige the political system had been housed since inaugurating the 1875 constitution?

A modified power sharing arrangement did not crudely come down to commoners supplanting the nobles in 
government, or politically dictating to the landed gentry by mere fact of outnumbering their seats, seventeen to nine, in the legislature. Ill-advisedly during Tonga's 2010 to 2014 attempt at getting the amended political system to function, this became the version that had flourished among opposition members of the commoner class, who in turn, churned out simplistic rhetoric to the public.

Basically, one side could not dominate the other. If a power shift swung inflexibly and single-mindedly one way to the people's representatives, or in the opposite direction to the nobles' representatives, Tongan civilization and culture at the crossroad of reform splintered into chaos and confusion.

For Tonga's parliamentary system to stay upright the key was pinpointing a workable composition of representatives in the legislative assembly whose political principles were tolerable to both the commoners and the nobles. Realistically, the Tongan state was socially insular, and the political buoyancy of government depended on leaders. Grooming leaders competent to fulfil state and cultural obligations under a constitutional monarchy in which the King's executive authority had not been reduced to ceremonial power, was in fact, a tall order where suitable front-runners were scarce.

In 2006, ten days before the eruption of the November 16th Nuku'alofa riot that destroyed eighty per cent of Tonga's central business district, United States Ambassador Larry Dinger wrote the Secretary of State's office in Washington DC. Retracing his conversation with the former Tongan Prime Minister Feleti Sevele in Suva, Fiji before the annual Pacific Islands Forum gathering, Dinger acknowledged that it was, to a considerable extent, the constitutional will of King George Tupou V's executive authority as reigning monarch that influenced how "significant" the democratic reforms would be in real-life practice (Dinger, 2006). 
Whatever thoughts and opinions were transacted from the late King George Tupou V directly to the prime minister of the time, Feleti Sevele, and vis-à-vis will never be truly known; only recorded in snippets and fragments of the actual conversation recalled and retold by Sevele to Dinger. Perhaps Larry Dinger had embellished his reading of what Sevele said to him. My point is, the reader does not know the contextual detail of how the conversation took place between this Tongan premier and a United States ambassador, who initiated the discussion, and what Dinger's impressions connote in respect to what was accurately and verifiably spoken between him and Sevele.

One conversation point relevant today is Sevele's position that "the King and the Nobles must remain players in the Tongan system, even if they no longer dominate" (Dinger, 2006). At present, this indicates a general view among Tongan voters after four years of piloting the reformed political system during the Tu'ivakano government's 2010 to 2014 term.

In conversations with the King, [Prime Minister Feleti] Sevele had also received the distinct impression that, while the King has no problem with significant reforms, including the prospect of an all-elected Parliament, the King also prefers instituting reforms by "convention, not legislation." Sevele believes the King and the Nobles must remain players in the Tongan system, even if they no longer dominate. The PM's [Prime Minister's] road map is intended to preserve the elite's roles, at least for the immediate future. (Dinger, 2006).

Why was radical change constitutionally proscribing the Tongan monarch from holding the executive authority to sanction legislation passed in the House under the advice of Privy Council law lords not a popular standpoint in Tonga? Stability was the social gage. Despite occasional evocations 
spouted from people's representatives elected to parliament on the opposition bench that Tonga should, in theory, pursue a Western liberal democracy model, the reigning monarch was the lynchpin to maintaining political stability and social order.

In brief, the monarchy and to a certain extent, the nobility, embodied fundamental points of reference as to how Tongan civilization and culture operated in the modern world, and was accepted and understood by its citizens to be uniquely Tongan. To eradicate the cultural presence of the ruling class in national political structure stirred an overwhelming risk in the Tongan psyche that the organisational culture was crudely dysfunctional, and furthermore, failed to distinguish Tongan state and society from all others, especially Westerners.

Tonga was never Western in historical origin, human consciousness, and political practice to begin with. Modern Tonga might have selectively borrowed and adapted political mechanisms from the British Westminster parliamentary system, but all apparatus of the state was reshaped to integrate into the existing structure of civilization and culture. Emphasising this line of reasoning as my final comment, I end this essay with Russian academic Mark Sleboda's thoughts on Huntington's "civilization clash" and Western neo-liberal trade intentions to "cement the Pacific in with the United States" (Lavelle, 2014d).

Mark Sleboda:Huntington said in the emerging world of ethnic conflict and civilizational clash, the Western belief in the universality of Western values suffers three problems. It is false. It is amoral. And it is dangerous. That is exactly what we've seen with this attempt to spread Western values both by hook and crook, first through the vector of neo-liberal globalisation and consumerism. 
The US [United States] is trying to build a multipolar world, it recognises it's happening. But it wants it to emerge in a form that is of its own choosing and that it feels is reflective of its values. And the way it hopes to do that is by tying the rest of the world into the institutions of global governance and other international organisations which propagate its values. And they've run into a number of problems. The complete failure of the G8. The subversion of the G20. The failure of the World Trade Organisation to continue its mission. And I think we can look at the Trans Pacific Partnership as one of the last big gasps.

And it's not only an attempt to neo-liberally cement the Pacific in with the United States with this free trade agreement, but it will also be the core, the economic core if you will, to further the development of a military sphere of containment, an alliance against an emerging China in the Pacific. I think most of the world should probably hope that this attempt to construct the Trans Pacific Partnership fails. (Lavelle, 2014d). 


\section{References}

'Akau'ola. (2014). Lightening Round Kick Starter: Accelerating Country Action. Sustainable Energy for All Forum, United Nations Headquarters, New York, United States, June 4. Retrieved from

http://webtv.un.org/meetings-events/index.php/watch/day-1afternoon-tcc-part-2-sustainable-energy-for-all-forum-4-6june-2014/3606309488001

Al Jazeera. (2014). Timeline: Ukraine political crisis. Al Jazeera, Doha, Qatar, May 15. Retrieved from

http://www.aljazeera.com/news/europe/2014/03/timelineukraine-political-crisis-201431143722854652.html

Aotearoa. (2014). John Key visits Obama during Iraq crisis: Will NZ soldiers die for a UN Security Council seat? Aotearoa: A Wider Perspective, New Zealand, June 16. Retrieved from http://aotearoaawiderperspective.wordpress.com/2014/06/16/jo hn-key-visits-obama-during-iraq-crisis-will-nz-soldiers-die-iniraq-for-a-un-seat/

Australian Broadcasting Corporation. (2014a). Fiji accuses global community of abandoning the Pacific on climate change, singles out 'selfish' Australia. Australian Broadcasting Commission: Australian Network News, Melbourne, Australia, June 19. Retrieved from

http://www.abc.net.au/news/2014-06-19/fiji-leader-accusesglobal-community-of-abandoning-the-pacif/5536274

Australian Broadcasting Corporation. (2014b). Fact file: How does the Renewable Energy Target affect your power bill? Australian Broadcasting Corporation: News, Melbourne, Australia, March 14. Retrieved from

http://www.abc.net.au/news/2014-03-07/how-does-therenewable-energy-target-affect-your-power-bill/5253136

Bauman, Z. (2011). Zygmunt Bauman: No one is in control. That is the major source of contemporary fear. The Guardian, London, United Kingdom, September 6. Retrieved from https://www.youtube.com/watch?v=73Nmv-4jvSc

BBC. (2014). Ukraine crisis timeline. British Broadcasting Corporation, London, United Kingdom, June 7. Retrieved from 
http://www.bbc.com/news/world-middle-east-26248275

Beehive. (2014). PM Key to meet US President at White House. Beehive Government New Zealand, Wellington, New Zealand, May 20. Retrieved from

http://www.beehive.govt.nz/release/pm-key-meet-us-presidentwhite-house

Bhattacharya, S. (1983). History from Below. Social Scientist, 11 (4): 3-20.

Brown Pulu, T. (2014). Off the Deep End: Continental Shelf Politics. Te Kaharoa: The e Journal of Indigenous Pacific Issues, 7 (1): 173-244.

Dinger, L. (2006). Next Step's in Tonga's Political Reform. Email Correspondence of United States Embassy in Suva, Fiji, to the Secretary of State, Washington DC, United States, November 6. Retrieved from

http://cables.mrkva.eu/cable.php?id=84573

Escobar, P. (2014). Pepe Escobar: Thailand's coup in four minutes. Russia Today, Moscow, Russian Federation, May 22. Retrieved from

https://www.youtube.com/watch?v=5mFGy2W0jhA\&feature=yout ube_gdata_player

Fanon, F. (2008). Black Skin, White Masks. New York, United States: Grove Press.

Firth, S. (Ed.) (2006). Globalisation and Governance in the Pacific Islands. Canberra, Australia: ANU E Press.

Folau, L. (2014). New Zealand provides million-dollar support to stadium and education. Matangi Tonga Online, Nuku'alofa, Tonga, June 4. Retrieved from

http://matangitonga.to/2014/06/04/nz-provides-million-dollarsupport-stadium-and-education

Fonua, P. (2014). Tonga's biggest national budget depends on aid. Matangi Tonga Online, Nuku'alofa, Tonga, June 11. Retrieved from

http://matangitonga.to/2014/06/11/tongas-biggest-nationalbudget-depends-aid 
Fonua, P. (2011). House pledges support to the king and thanks god for aid donors. Matangi Tonga Online, Nuku'alofa, Tonga, June 9. Retrieved from

http://matangitonga.to/2011/06/09/house-pledges-supportking-and-thanks-god-aid-donors

Fukuyama, F. (1992). The End of History and the Last Man. New York, United States: The Free Press.

Garrett, J. (2014). Unfinished business in Tonga's political reform says expert. Radio Australia: Pacific Beat, Australian Broadcasting Corporation, Melbourne, Australia, April 30. Retrieved from

http://www.radioaustralia.net.au/international/radio/program/p acific-beat/unfinished-business-in-tongas-politcal-reformneeds-attention-says-expert/1303624

Government of Tonga. (2011). Cabinet retreat targets strategic plans for Tonga's future: Press Release - Government of Tonga. Government of Tonga, Nuku'alofa, Tonga, reposted in Pacific Scoop: AUT's Pacific Media Centre, May 24. Retrieved from

http://pacific.scoop.co.nz/2011/05/cabinet-retreat-targetsstrategic-plans-for-tonga $\% \mathrm{E} 2 \% 80 \% 99$ s-future/

Hao'uli, S. (2014). Email Correspondence to Teena Brown Pulu, Auckland, New Zealand, June 6.

Harmon, P. K. (2011). What Island: Poems. Madison, New Jersey, United States: Serving House Books.

Hayward-Jones, J. and Newton Cain, T. (2014). Quick Comment: Jenny Hayward-Jones and Tess Newton Cain on the Pacific Islands Development Forum. Lowy Institute, Sydney, Australia, June 20. Retrieved from

https://soundcloud.com/lowyinstitute/pacific-islandsdevelopment-forum

Hill, B. (2010). King Tupou V speaks to Radio Australia. Australian Broadcasting Commission News: Radio Australia, Melbourne, Australia, November 22. Retrieved from

http://www.abc.net.au/news/2010-11-22/king-tupou-v-speaksto-radio-australia/2346566 
Huntington, S. P. (1997). The Clash of Civilizations and the Remaking of World Oder. United Kingdom: Simon and Schuster United Kingdom Limited.

Huntington, S. P. (1993). The Clash of Civilizations? Foreign Policy, (Summer): 22-49.

International Business Publications. (2011). Tonga: Foreign Policy and Government Guide: Volume 1, Strategic Information and Developments. Washington DC, United States: International Business Publications, USA.

IRENA. (2013). Press Releases: IRENA welcomes the "Renewables Club." International Renewable Energy Agency, Abu Dhabi, United Arab Emirates, June 4. Retrieved from

http:/ / www.irena.org/News/Description.aspx?NType=A\&PriMenuI $\underline{D=16 \& \text { catid }=84 \& m n u=\text { cat\&News_ID }=317}$

Karmanau, Y. and Isachenkov, V. (2014). Vladimir Putin admits for first time Russian troops took over Crimea. Associated Press, New York, United States, April 17. Retrieved from http://zzwave.com/plaboard/posts/3935324.shtml

Latu, K. (2014a). Near-brawl ends Tonga Democratic Party's meeting. New Zealand Kaniva Pacific, Auckland, New Zealand, June 13. Retrieved from

http://www.nzkanivapacific.co.nz/2014/06/near-brawl-endstonga-democratic-partys-meeting/\#.U5rGcShWnTo

Latu, K. (2014b). Tonga Democratic Party unlikely to change Party MPs. New Zealand Kaniva Pacific, Auckland, New Zealand, June 2. Retrieved from

http://www.nzkanivapacific.co.nz/2014/06/tonga-democraticparty-unlikely-change-party-mps/\#.U42OiyhWnTo

Lavelle, P. (2014a). Bleeding Ukraine: Crosstalk with Graham Phillips, David Speedie, David Robles. Russia Today, Moscow, Russian Federation, May 30. Retrieved from

https: / / www.youtube.com/watch?v=gZqCm7pyZCY\&feature=yout ube_gdata_player 
Lavelle, P. (2014b). On the Money: Who pays the price for info wars? (Featuring Pepe Escobar and Ben Aris). Russia Today, Saint Petersburg, Russian Federation, May 28. Retrieved from https://www.youtube.com/watch?v=35uEP2vAvAc\&feature=youtu be_gdata_player

Lavelle, P. (2014c). Media Madness: Crosstalk with Manuel Ochsenreiter and Dmitry Babich. Russia Today, Moscow, Russian Federation, May 24. Retrieved from

https://www.youtube.com/watch?v=V54ycIPMMaM\&feature=yout ube_gdata_player

Lavelle, P. (2014d). Multipolar Order: Crosstalk with Rodney Shakespeare, Ehsan Ahrari, Mark Sleboda. Russia Today, Moscow, Russian Federation, May 19. Retrieved from

https://www.youtube.com/watch?v=6s0nlDIzxjM\&feature=youtub e_gdata_player

Lavelle, P. (2014e). Ukrainian Red Lines: Crosstalk with Martin McCauley, Michael Hudson, and Daniel Welch. Russia Today, Moscow, Russian Federation, May 14. Retrieved from

https://www.youtube.com/watch?v=3paG2cdC8Mg\&feature=y outube_gdata_player

Lavelle, P. (2014f). Ukraine vs Ukraine: Crosstalk with Kevin Barrett, Charles Shoebridge, and Andrew Korybko. Russia Today, Moscow, Russian Federation, May 12. Retrieved from

https://www.youtube.com/watch?v=KQ41_o52yvs\&feature=youtu $\underline{\text { be_gdata_player }}$

Lavrov, S. (2014). Lavrov: Americans are not ready to admit they cannot run the show. Russia Today, Moscow, Russian Federation, April 23. Retrieved from

https://www.youtube.com/watch?v=ZxbSmNZVsBI

Lavrov, S. (2013). Lavrov: 6-9 months enough to resolve Iran nuclear issue. Russia Today, Moscow, Russian Federation, October 8. Retrieved from

http://rt.com/politics/official-word/iran-cooperation-interviewlavrov-904/

Lavrov, S. (2012a). Fiji Visit by Russian Foreign Minister: Fiji Ceremonies. Ministry of Foreign Affairs, Government of the 
Republic of the Fiji Islands, Suva, Fiji, February 1. Retrieved from

https://www.youtube.com/watch?v=KQv4Qnt_TfA

Lavrov, S. (2012b). Russian Foreign Minister's Visit. Ministry of Foreign Affairs, Government of the Republic of the Fiji Islands, Suva, Fiji, February 1. Retrieved from

https://www.youtube.com/watch?v=buLWDMA_bXc

Lavrov, S. (2009). Russian Foreign Minister Sergey Lavrov: International Relations in the New Coordinate System. Maxims News Network: News Network for the United Nations and the International Community, New York, United States, September 13. Retrieved from

http://www.maximsnews.com/news20090913russiasergeylavrov1 $\underline{0909130101 . \mathrm{htm}}$

Lieven, A. and Hulsman, J. (2006). Ethical Realism: A Vision for America's Role in the World. New York, United States: Pantheon Books, Random House.

Matangi Tonga. (2014a). Lord Fusitu'a takes father's seat. Matangi Tonga Online, Nuku'alofa, Tonga, May 22. Retrieved from

http://matangitonga.to/2014/05/22/lord-fusitua-takes-fathersseat

Matangi Tonga. (2014b). King opens new commercial bank. Matangi Tonga Online, Nuku'alofa, Tonga, April 7. Retrieved from

http://matangitonga.to/2014/04/07/king-opens-newcommercial-bank

Matangi Tonga. (2013). China marks 64 anniversary. Matangi Tonga Online, Nuku'alofa, Tonga, September 27. Retrieved from

http://matangitonga.to/2013/09/27/china-marks-64thanniversary

Mearsheimer, J. (2014). The Tragedy of Great Power Politics: Updated Edition. New York, United States: W. W. Norton \& Company Limited, Incorporated. 
Meridian. (2014). Maama Mai. Meridian Energy New Zealand Limited, Wellington, New Zealand, June 14. Retrieved from

http://www.meridianenergy.co.nz/about-us/generatingenergy/solar/maama-mai/

Moore, C. (2014). Empires of the Coral Sea. In The Routledge History of Western Empires, edited by R. Aldrich and K. McKenzie. New York, United States: Routledge, Pp. 151- 164.

Naidu, V. (2006). The State of the State in Fiji: Some failings in the periphery. In Globalisation and Governance in the Pacific Islands, edited by S. Firth. Canberra, Australia: ANU E Press, Pp. 297-315.

Oborne, P. (2013). Sergey Lavrov: An essential new voice has emerged in world affairs. The Telegraph, London, United Kingdom, October 11. Retrieved from

http://blogs.telegraph.co.uk/news/peteroborne/100241007/serg ey-lavrov-an-essential-new-voice-has-emerged-in-worldaffairs/

Oliver, A. (2014). The Lowy Institute Poll 2014. Sydney, Australia: Lowy Institute, Pp. 1-34.

Plokhy, S. (2014). The Last Empire: The Final Days of the Soviet Union: Carnegie Council Events. Carnegie Council, New York, United States, June 3. Retrieved from

http://www.ustream.tv/recorded/48331959

Poling, G. (2014). Abbott's and Key's Washington Visits: Deepening Two Pacific Partnerships. Centre for Strategic and International Studies, Washington DC, United States, June 5. Retrieved from

http://csis.org/publication/abbotts-and-keys-washington-visitsdeepening-two-pacific-partnerships

Prime Minister's Office. (2014a). Tonga's PM attends 2nd PIDF Summit. Government of Tonga, Ministry of Information and Communications, June 19. Retrieved from

http://www.mic.gov.to/news-today/press-releases/4990-tongaspm-attends-2nd-pidf-summit 
Prime Minister's Office. (2014b). New Zealand Prime Minister Rt Hon John Key to visit Tonga. Government of Tonga, Ministry of Information and Communications, June 4. Retrieved from http://www.mic.gov.to/news-today/press-releases/4971-newzealand-prime-minister-rt-hon-john-key-to-visit-tonga

Radio New Zealand. (2014a). Tonga Govt queries power hikes. Radio New Zealand International, Auckland, New Zealand, June 16. Retrieved from

http://www.radionz.co.nz/international/pacificnews/247336/tonga-govt-queries-power-hikes

Radio New Zealand. (2014b). Tonga budget relies heavily on aid. Radio New Zealand International, Auckland, New Zealand, June 12. Retrieved from

http://www.radionz.co.nz/international/pacificnews/247013/tonga-budget-relies-heavily-on-aid

Radio New Zealand. (2014c). Debt concerns over Tonga budget. Radio New Zealand International, Auckland, New Zealand, June 12. Retrieved from

http://www.radionz.co.nz/international/pacificnews/247037/debt-concerns-over-tonga-budget

Radio New Zealand. (2014d). Reports Tonga's Democrats in disarray. Radio New Zealand International, Auckland, New Zealand, June 6. Retrieved from

http://www.radionz.co.nz/international/pacificnews $/ 246521 /$ reports-tonga $\% 27$ s-democrats-in-disarray

Radio New Zealand. (2014e). Tonga union queries appointment process. Radio New Zealand International, Auckland, New Zealand, June 6. Retrieved from

http://www.radionz.co.nz/international/pacificnews/246511/tonga-union-queries-appointment-process

Radio New Zealand. (2014f). Tonga PSA being sued by the PM. Radio New Zealand International, Auckland, New Zealand, May 29. Retrieved from

http://www.radionz.co.nz/international/pacificnews/245768/tonga-psa-being-sued-by-the-pm 
Samuels, L. (2014). Up to Speed: All You Need to Know About the Thailand Coup. The Daily Beast, United States, May 27. Retrieved from

http://www.thedailybeast.com/articles/2014/05/27/up-tospeed-what-you-need-to-know-about-the-thai-coup.html

Scarr, D. (1967). Fragments of Empire: A History of the Western Pacific High Commission, 1877 - 1914. Canberra, Australia, and London, United Kingdom: Australian National University Press and C. Hurst and Company.

Small, V. (2014). Tonga defends China aid. Stuff Co NZ: Politics, Auckland, New Zealand, June 5. Retrieved from

http://www.stuff.co.nz/national/politics/10121941/Tongadefends-China-aid

Tonga Energy Road Map. (2013). Lord Tu'ivakano takes Pacific concerns to first Asia Pacific Energy Forum. Tonga Energy Road Map, Nuku'alofa, Tonga, June 25. Retrieved from

http://energy.gov.to/index.php/news/212-lord-tu-ivakano-takespacific-concerns-to-first-asia-pacific-energy-forum

Stanford, J. (2014). Key to visit Tonga. Newstalk ZB: New Zealand News, Auckland, New Zealand, June 1. Retrieved from

http://www.newstalkzb.co.nz/auckland/news/nbnat/374079626 -key-to-visit-tonga

Sustainable Energy for All. (2014). Tonga Solar Power Plant. Sustainable Energy for All, United Nations Headquarters, New York, United States, June 14. Retrieved from

http://www.se4all.org/commitment/tonga-solar-power-plant/

Switzer, T. (2014). Obama at West Point: The limits of American power. The Interpreter, Lowy Institute, Sydney, Australia, May 29. Retrieved from

http://www.lowyinterpreter.org/post/2014/05/29/Obama-atWest-Point.aspx

Tora, I. (2014). Vaini solar farm third in project. Tonga Daily News, Nuku'alofa, Tonga, February 4. Retrieved from http://www.tongadailynews.to/?p=3315 
Tu'ivakano. (2014). Small Islands, Big Problems, Complex Solutions. The Straits Times, Singapore, June 12. Retrieved from

http://www.straitstimes.com/news/opinion/more-opinionstories/story/small-islands-big-problems-complex-solutions$\underline{20140610}$

TVNZ. (2014). John Key in US for week-long talks. TVNZ: ONE News, Auckland, New Zealand, June 16. Retrieved from

http://tvnz.co.nz/national-news/john-key-in-us-week-long-talks$\underline{6004236}$

United Nations. (2014a). World Environment Day: SIDS and Clean Energy. Sustainable Energy for All Forum, United Nations Headquarters, New York, United States, June 5. Retrieved from

http://webtv.un.org/meetings-events/index.php/watch/day-2world-environment-day-sustainable-energy-for-all-forum-4-6june-2014/3608084859001

United Nations. (2014b). The United Nations World Water Development Report 2014: Water and Energy, Volume 1. Paris, France: United Nations Education, Scientific and Cultural Organization (UNESCO), Pp. 1-230.

United Nations ESCAP. (2013). The Asian and Pacific Energy Forum. United Nations Economic and Social Commission for Asia and the Pacific (ESCAP), Bangkok, Thailand, May 27 - 30. Retrieved from

http://www.unescap.org/events/asian-and-pacific-energy-forum

University of the South Pacific. (2012). Tonga workshop - a catalyst for national action in renewable energy. The University of the South Pacific: News at USP, Suva, Fiji, April 18. Retrieved from

http://www.usp.ac.fj/news/story.php?id=1003

White House. (2014). Statement by the Press Secretary on the Visit of Prime Minister John Key of New Zealand. The White House: Office of the Press Secretary, Washington DC, United States, May 19. Retrieved from

http://www.whitehouse.gov/the-pressoffice/2014/05/19/statement-press-secretary-visit-primeminister-john-key-new-zealand 
Xinhua. (2014). "Inclusive" PIDF summit concludes with commitment on partnership, green/blue growth. Xinhua: English News, Nadi, Fiji, June 20. Retrieved from http://news.xinhuanet.com/english/world/2014$\underline{06 / 20 / C \_133423218 . h t m}$ 